\title{
Achieving Knowing and Voluntary Consent in Pre-Dispute Mandatory Arbitration Agreements at the Contracting Stage of Employment
}

\author{
Christine M. Reilly†
}

TABLE OF CONTENTS

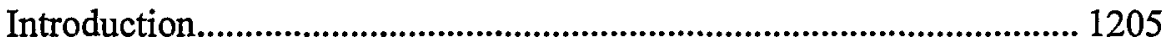

I. Overview of Pre-Dispute Mandatory Arbitration Agreements ....... 1208

A. The Significance of PMAAs...................................................... 1209

B. The Early Mandatory Arbitration Cases ................................... 1213

C. The Current State of the Law..................................................... 1215

1. Judicial Review of PMAAs............................................. 1215

a. The Knowing and Voluntary Standard ........................ 1216

b. The Appropriate Standard............................................. 1218

c. The Contractual Standard ............................................. 1219

2. Executive Response to PMAAs ....................................... 1220

3. Legislative Response to PMAAs........................................ 1222

II. Barriers to Achieving Knowing and Voluntary Consent ................ 1224

A. The Elusive Meaning of "Knowing and Voluntary" ................. 1224

B. Misconceptions About the Law ................................................. 1225

C. Cognitive Biases ...................................................................... 1228

1. Optimistic Bias and Poor Risk Perception ....................... 1228

Copyright (c) 2002 California Law Review, Inc. California Law Review, Inc. (CLR) is a California nonprofit corporation. CLR and the authors are solely responsible for the content of their publications.

$\dagger$ Law Clerk, The Honorable Helen Gillmor, United States District Court, District of Hawaii; J.D., School of Law, University of California, Berkeley (Boalt Hall), 2002; B.S., School of Industrial \& Labor Relations, Cornell University, 1997. I would like to extend my sincere thanks to Professor Linda Hamilton Krieger for her intellect, inspiration, and guidance in helping me complete this project. I would also like to thank Professors Melvm A. Eisenberg and Robert J. MacCoun for their assistance on the cognitive bias material. I am particularly grateful to California Law Review Managing Editor Brian MeDonald for improving this Comment in innumerable ways. This Comment has also benefited significantly from edits by CLR editors Jason Bezis and Janet Tung. My appreciation also extends to other CLR members for their work, including Christine Duh, Jon Eldan, Andrea Goldsmith, Chris Hazuka, Rebecca Lynch, and Limm Zheng. Boalt Hall students Meg Vasey ('200I) and Kate Gordon (2002) also made valuable contributions. Last, but certaimly not least, thank you to the members of the Berkeley Journal of Employment \& Labor Law-Shawna Ogden, Eddie Genna, Julia Laurin, Katherine Fosseen, and Megan Lane-for all your support and patience during the writing of this Comment. All of you are not only my colleagues but dear friends. 
2. Representative Heuristics and Faulty Schemas................. 1230

D. Coercive Condition of Employment ...................................... 1234

1II. Knowing and Voluntary Consent Under the Older Workers

Benefit Protection Act.................................................................. 1238

A. The OWBPA..................................................................... 1238

B. OWBPA's Knowing and Voluntary Consent Model................. 1240

C. Applying the OWBPA's Consent Model to PMAAs................. 1241

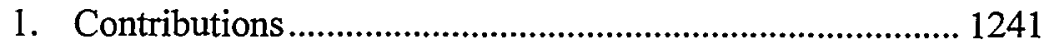

2. Shortcomings............................................................. 1242

IV. The Meaningful Choice and Informed Consent Regime................. 1245

A. Instilling Meaningful Choice ................................................ 1245

B. Educating Through Informed Consent...................................... 1251

C. Alleviating Cognitive Bias..................................................... 1255

D. Defining "Knowing and Voluntary".................................... I257

E. Implementing the Proposed Regime ..................................... 1258

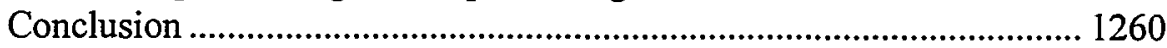




\title{
Achieving Knowing and Voluntary Consent in Pre-Dispute Mandatory Arbitration Agreements at the Contracting Stage of Employment
}

\author{
Christine M. Reilly
}

I agree that I will settle any and all previously unasserted claims, disputes or controversies arising out of or relating to my application or candidacy for employment, employment and/or cessation of employment with Circuit City, exclusively by final and binding arbitration before a neutral Arbitrator. ${ }^{1}$

\section{INTRODUCTION}

In 1995, Saint Clair Adams signed an employment application containing the above provision when he applied for a job at Circuit City, a national retailer of consumer electronics, in Santa Rosa, California. Two years later, Adams filed an employment discrimination suit against Circuit City in California state court. Circuit City filed suit in federal court, seeking to enjoin the state action and compel arbitration pursuant to the Federal Arbitration Act ("FAA"). The District Court for the Northern District of California granted Circuit City's request, but the Ninth Circuit reversed, holding that the FAA does not apply to employment contracts. ${ }^{2}$ In Circuit City v. Adams, the United States Supreme Court reversed the Ninth Circuit, prohibiting Adams from bringing his employment case before a judge or jury and requiring him to submit his claim to an arbitrator. ${ }^{3}$

When Adams signed Circuit City's employment application, he waived his right to have future employment disputes decided by a jury of his peers. He waived the right to litigate claims under federal, state, and local statutory or common law, including claims under the Age

1. Circuit City Stores, Inc. v. Adams, 532 U.S. 105, 109-10 (2001) (quoting respondent's employment application).

2. Circuit City Stores, Inc. v. Adams, 194 F.3d 1070, 1071-72.

3. Circuit City Stores, Inc. v. Adams, 532 U.S. 105 (2001). On remand, however, the Ninth Circuit held that the arbitration agreement was both procedurally and substantively unconscionable, and thus unenforceable, as a matter of California law. It was procedurally unconscionable because it was an adhesion contract offered on a take-it-or-leave-it basis. It was substantively unconscionable because the agreement required arbitration of employee (but not employer) claims, limited the remedies for which the employee would be eligible under state law, required the employee to pay one-half of the arbitrator's fee, and contained a strict one year statute of limitations. Circuit City Stores, Inc. v. Adams, 279 F.3d 889 (9th Cir. 2002), petition for cert. filed, Apr. 3, 2002 (No. 01-1460). 
Discrimination in Employment Act ("ADEA"), Title VII of the Civil Rights Act, and the Americans with Disabilities Act ("ADA"). ${ }^{4}$ The application Adams signed contained a mandatory arbitration clause that restricted his back pay to one year, front pay to two years, and punitive damages to the greater of the amount of front and back pay awarded or $\$ 5000$. It required him to split the total costs of arbitration unless he prevailed and the arbitrator awarded him the arbitration costs. Although Circuit City's agreement required Adams to settle all disputes through arbitration, Circuit City itself was not required to arbitrate any of its claims against him. It retained the unfettered right to bring those claims before a judge or jury.

Like most applicants who sign pre-dispute mandatory arbitration agreements, Adams probably failed to read the entire application when he signed it. Even if he did read it, he probably knew little, if anything, about the ramifications of the arbitration clause. Like most applicants, Adams probably lacked the proper legal knowledge and cognitive capabilities to truly understand and evaluate the agreement. Moreover, he was compelled to sign it if he really wanted the job since Circuit City does not even consider applicants who fail to sign the mandatory arbitration agreement. ${ }^{5}$ Simply put, Adam's choice was to give up his right to go to court or give up his job. ${ }^{6}$ It is this type of dispute resolution clause known in the mdustry as a pre-dispute mandatory arbitration agreement ("PMAA") that is the focus of this Comment.

PMAAs have been the subject of a lively public policy debate among legislators, courts, administrative agencies, alternative dispute resolution providers, and legal scholars. Many have argued for their abolition, ${ }^{7}$ and at

4. Adams, 279 F.3d at 891 n.1.

5. Id. at 891-92.

6. The Dunlop Commission on the Future of Worker-Management Relations: Final REPORT, at http://ilr.cornell.edu/library/e_archive/gov_reports/dunlop/DunlopFinalRcport.pdf, at 59 (last visited Mar. 8, 2002). See also Miriam A. Cherry, Note, Not-So-Arbitrary Arbitration: Using Title VII Disparate Impact Analysis to Invalidate Employment Contracts that Discriminate, $21 \mathrm{HARv}$. WOMEN's L.J. 267 (1998) ("[T]he prospective employee really only has two options: take the job with the arbitration clause or turn down the work altogether.")

7. Richard M. Alderman, Pre-Dispute Mandatory Arbitration in Consumer Contracts: A Call for Reform, 38 Hous. L. REv. 1237 (2001); John-Paul Motley, Compulsory Arbitration Agreements in Employment Contracts from Gardner-Denver to Austin: The Legal Uncertainty and Why Employers Should Choose Not to Use Prcemployment Arbitration Agreements, 51 VAND. L. REv. 687 (1998); John Vail, Defeating Mandatory Arbitration Clauses, TrIaL, January, 2000; Katherine Eddy, Note, To Every Remedy a Wrong: The Confounding of Civil Liberties Through Mandatory Arbitration Clauses in Employment Contracts, 52 Hastings L.J. 771, 791 (2001); Colin P. Johnson, Comment, Has Arbitration Become a Wolf in Sheep's Clothing?: A Comment Exploring the Incompatibility Between Pre-Dispute Mandatory Binding Arbitration Agreements in Employment Contracts and Statutorily Created Rights, 23 Hamline L. Rev. 511 (2000). See also EEOC Policy Statement on Mandatory Arbitration, DaILY LAB. REP. (BNA) No. 133, July 11, 1997, at E-4 [hereinafter EEOC Policy Statement]; Cherry, supra note 6. 
least one scholar has argued for certain limits on their use. ${ }^{8}$ While abolition is a tempting alternative, Circuit City v. Adams demonstrates that mandatory arbitration is unlikely to be eliminated anytime in the near future. ${ }^{9}$ The Supreme Court remains steadfastly in favor of mandatory arbitration and continues to uphold these agreements. Absent congressional intervention, mandatory arbitration is here to stay.

Many scholars have argued that a knowing and voluntary standard of consent should be applied to these agreements. ${ }^{10}$ In particular, many advocate adopting the knowing and voluntary consent model from the Older Workers Benefit Protection Act ("OWBPA") of the ADEA. " While such a heightened standard of consent seems at first glance to be an appropriate solution, no one has suggested exactly how such a knowing and voluntary consent standard would work in the pre-employment context. This Comment tackles this perplexing issue and proposes a new standard of consent to govern these agreements.

8. In a thoughtful piece, Sarah Cole argues that enforcement of arbitration agreements should be limited to parties who have similar negotiating imcentives such as repeat players. Simce the bargaining power between employees and employers is so unevenly balanced in favor of the employer, Cole argues that such agreements should be entirely prohibited. Sarah Rudolph Cole, Incentives and Arbitration: The Case Against Enforcement of Executory Arbitration Agreements Between Employers and Employees, 64 UMKC L. REv. 449 (1996).

9. See Jennifer N. Manuszak, Pre-Dispute Civil Rights Arbitration in the Nonunion Sector: The Need for a Tandem Reform Effort at the Contracting, Procedural and Judicial Review Stages, 12 Oн10 ST. J. ON DisP. RESOL. 387, 422 (1997) (arguing that mandatory arbitration is unlikely to be abolished since federal courts have embraced pre-dispute arbitration of civil rights since Gilmer $v$. Interstate/Johnson Lane Corp., 500 U.S. 20 (1991)).

10. See Ellwood F. Oakley, III \& Donald O. Mayer, Arbitration of Employment Discrimination Claims and the Challenge of Contemporary Federalism, 47 S.C. L. Rev. 475 (1996); Richard C. Reuben, Constitutional Gravity: A Unitary Theory of Alternative Dispute Resolution and Public Civil Justice, 47 UCLA L. Rev. 949 (2000); Richard E. Speidel, Consumer Arbitration of Statutory Claims: Has Pre-Dispute (Mandatory) Arbitration Outlived Its Welcome?, 40 ARIZ. L. Rev. 1069 (1998); Jean R. Sternlight, Mandatory Binding Arbitration and the Demise of the Seventh Amendment Right to a Jury Trial, 16 OHIo ST. J. ON DisP. ReSOL. 669 (2001); Ronald Turner, Employment Discrimination, Labor and Employment Arbitration, and the Case Against Union Waiver of the Individual Worker's Statutory Right to a Judicial Forum, 49 EMORY L.J. 135 (2000); Chenry, supra note 6; Monica J. Washington, Note, Compulsory Arbitration of Statutory Employment Disputes: Judicial Review Without Judicial Reformation, 74 N.Y.U. L. REv. 844 (1999).

I1. Robert Belton, The Unfinished Agenda of the Civil Rights Act of I99I, 45 RUTGERS L. REv. 921 (1993); Andrea Fitz, The Debate over Mandatory Arbitration in Employment Disputes, 54 DisP. RESOL. J. 35 (1999); Joseph R. Grodin, Arbitration of Employment Discrimination Claims: Doctrine and Policy in the Wake of Gilmer, 14 HoFstra LAB. L.J. 1 (1996); Karen Halverson, Arbitration and the Civil Rights Act of 1991, 67 U. Cin. L. Rev. 445 (1999); William M. Howard, Arbitrating Employment Discrimination Claims: Do You Really Have To? Do You Really Want To?, 43 DraKe L. REv. 255 (1994); Manuszak, supra note 9; Note, Mandatory Arbitration of Statutory Employment Disputes, I09 HARv. L. Rev. 1670 (1996); Beth A. Rowe, Comment, Binding Arbitration of Employment Disputes: Opposing Pre-Dispute Agreements, 27 U. ToL. L. REv. 921 (1996); Cf. Samuel Estreicher, Predispute Agreements to Arbitrate Statutory Employment Claims, 72 N.Y.U. L. REv. 1344, 1358 (1997) (arguing against tests of volnntariness beyond mere contractual principles); Stephen J. Ware, Consumer Arbitration as Exceptional Consumer Law (With a Contractualist Reply to Carrington \& Haagen), 29 MCGEORGE L. REv. 195 (1998) (advocating a contractual approach over a knowing and voluntary standard). 
Part I outlines the definition, significance, and history of PMAAs in the employment realm. Part II critically analyzes the concept of "knowing and voluntary consent" in the PMAA context and the various barriers to establishing a truly knowing and voluntary consent standard. Part III evaluates a proposed solution to the current controversy-applying the knowing and voluntary consent model of the OWBPA to PMAAs. Finally, Part IV proposes a modified version of the OWBPA consent model called the "Meaningful Choice and Informed Consent Regime" as a superior way to successfully establish a knowing and voluntary standard of consent to PMAAs at the contracting stage of employment.

\section{Overview of Pre-Dispute Mandatory Arbitration Agreements}

A pre-dispute mandatory arbitration agreement is a legally binding agreement that requires applicants to waive their rights to bring future claims before a jury, and instead, requires that those claims be subinitted to an arbitrator. ${ }^{12}$ The arbitration agreeinent may be given to the applicant separately, or as part of an employment agreement, application, or by reference to other documents such as employee manuals or handbooks. ${ }^{13}$ Typically, the employer will present the agreement to an applicant before or immediately after an offer of employment is inade. ${ }^{14}$ Most applicants must sign the agreement before they begin work. ${ }^{15}$

PMAAs have become prevalent in employment agreements. They are often boilerplate provisions in einployment contracts at Fortune 500 companies and are the norm in industries such as financial services, health care, engineering, and information technology. ${ }^{16}$ Until recently, they were boilerplate provisions in the securities industry as well. ${ }^{17}$ Nearly all private

12. PMAAs are distinguishable from post-dispute arbitration agreements, in which arbitration is proposed and agreed to after a dispute arises. In such cases, the employee has a choice: he or she can go to court or submit the claim to arbitration. Post-dispute arbitration is consensual and therefore invokes less controversy.

13. See Eddy, supra note 7, at 775 .

14. Employees may also be asked to sign a PMAA during their employment as a condition of continued employment. This Comment will not consider this latter type of PMAA, although most of the principles discussed herein are applicable to these agreements as well.

15. See Manuszak, supra note 9. See also Circuit City Stores, Inc. v. Adams, 279 F.3d 889, 89192 (9th Cir. 2002).

16. See Vail, supra note 7, at 70 ("Boilerplate mandatory arbitration clauses are showing up everywhere."); Beth E. Sullivan, Note, The High Cost of Efficiency: Mandatory Arbitration in the Securities Industry, 26 FoRdHAM URB. L.J. 311,313 (1999).

17. Employees who were broker-dealers under the Securities and Exchange Act of 1934 used to be required, as a condition of employment, to register with the National Association of Securities Dealers ("NASD") or the New York Stock Exchange ('NYSE") pursuant to Form U-4, which required that all employment disputes be submitted to mandatory binding arbitration. As of January 1, 1999, the NASD and the NYSE no longer require their securities industry employees to submit discrimination and sexual harassment claims to pre-dispute mandatory binding arbitration. The industry gave in to extreme pressure exerted by the plaintiffs' bar, civil rights groups, and Congress to eliminate the 
employers use some type of alternative dispute resolution mechanism to resolve disputes. ${ }^{18}$ Although it is unknown exactly how many employees must sign PMAAs to gam employment, about ten to twenty percent of the workforce is covered by a mandatory arbitration agreement. ${ }^{19}$ As of 1997 , arbitration agreements with the American Arbitration Association alone, ninety-five percent of which were PMAAs,${ }^{20}$ covered more than 3.5 million workers. ${ }^{21}$ This percentage is expected to grow dramatically as employment litigation expands. ${ }^{22}$

Although not a novel idea, PMAAs continue to generate controversy in employment law. ${ }^{23}$ In order to better understand this debate, this Comment will first explore the significance of PMAAs. Part I.A will analyze why PMAAs should, and do, matter in the employment context. Part I.B briefly explores the birth of PMAAs as a widespread phenomenon through a look at the early mandatory arbitration cases. Part I.C coinpletes the overview by discussing the current state of the law in the judiciary, executive, and legislative branches.

\section{A. The Significance of PMAAs}

The right to a jury trial is considered a fundamental constitutional guarantee. ${ }^{24}$ Congress's high regard for the right to a jury trial culminated

condition. However, all other types of employment claims still remain subject to mandatory arbitration and firms can separately insert arbitration agreements in employment contracts. See Peter M. Panken et al., Alternative Dispute Resolution in the Courts and the Real World, 03 A.L.I.-A.B.A. 263, 287 (2000); Sullivan, supra note 16, at 327-28. For a good recitation of the events leading up to the industry's limited abolition of PMAAs, see Paul Rose, Comment, Developing a Market for Employment Discrimination Claims in the Securities Industry, 48 UCLA L. REv. 399, 41 1-13 (2000).

18. Discrimination: Nearly All Private Employers Use ADR to Resolve Bias Disputes, GAO Study Finds, ER.P. PoL. \& L. DaILY (BNA), July 7, 1995, at D-4.

19. David E. Feller, Putting Gilmer Where It Belongs: The FAA's Labor Exemption, 18 Horstra LAB. \& EMP. L.J. 253, 253 (2000); Charlie Cray, See You in...Arbitration?, Multinational Monitor, Vol. 21, No. 12, at 4 (Dec. 1,2000), available at 2000 WL 16039275.

20. AAA General Counsel Discusses Nonunion Employment Disputes, EMP. POL. \& L. DAILY (BNA), Feb. 17, 1995, at D-9.

21. Voluntary Arbitration in Worker Disputes Endorsed by Two Groups, WALL ST. J., June 20, 1997, at B2.

22. See Andrew Kramer et al., Mandatory Arbitration as an Alternative Method of Resolving Workplace Disputes, 994 A.L.I.A.B.A. 177, 179 (1999) (explaiming that employment suits now account for the largest percentage of civil litigation). For other statistics demonstrating increases in employment litigation, see Naoko Miyamoto, From Mago to Duffield: Recent Developments in the Enforceability of Mandatory Arbitration Agreements of Title VII Claims in the Ninth Circuit, $21 \mathrm{U}$. HAw. L. Rev. 779 (1999). See also Cole, supra note 8, at 449 (explaining how judges have embraced arbitration as an alternative to resolving disputes as their workloads have increased while their resources have not).

23. See Litaker v. Lehman Bros. Holdings, Inc., No. 97-CIV-1607(DC), 1999 WL 619638, at ₹2 (S.D.N.Y. Aug. 17, 1999).

24. Dreiling v. Peugeot Motors of Am., Inc., 539 F. Supp. 402, 403 (D. Colo. 1982). One judge thinks the right to a jury trial is not only fundainental but malienable. Martens v. Smith Barney, Inc., 181 F.R.D. 243, 253-54 (S.D.N.Y. 1998) (Motley, J.). See also Byrd v. Blue Ridge Rural Elec. Coop., Inc., 356 U.S. 525 (1958) (strong federal interest in plaintiff's access to a jury trial under the Seventh 
in the passage of the Civil Rights Act of $1991,{ }^{25}$ which expressly created the right to a jury trial and to the recovery of compensatory and punitive damages in Title VII and ADA cases. Nevertheless, despite legislative esteem for this right, courts continue to uphold PMAAs, thereby requiring applicants to submit their claims to an arbitrator rather than a judge or jury. ${ }^{26}$

This waiver is even more significant when one considers the fact that numerous other procedural rights guaranteed at trial are also waived when a claim is arbitrated rather than litigated: ${ }^{27}$

[Applicants] effectively waive the following procedural rights: (1) their rights under Article I and Article III of the Constitution; (2) their rights under the 5th, 7th, and 14th Amendments; (3) their rights to demand that statutory employment discrimination claims be adjudicated in a federal district court under the Federal Rules of Civil Procedure and the Federal Rules of Evidence by a judge, appointed under Article III of the Constitution, who will provide instruction as to the applicable law to a jury chosen in a fair, objective, and non-discriminatory manner; and (4) their right to appeal an adverse verdict to a U.S. Court of Appeals or to petition for certiorari to the U.S. Supreme Court. ${ }^{28}$

Amendment); Nat'l Equip. Rental, Ltd. v. Hendrix, 565 F.2d 255, 258 (2d Cir. 1977) ("It is elementary that the Seventh Amendment right to a jury is fundamental and that its protection can only be relinquished knowingly and intentionally.").

25. Pub. L. No. 102-166, 105 Stat. 1071 (1991).

26. But see Rosenberg v. Merrill Lynch, Pierce, Fenner \& Smith, Inc., 995 F. Supp. 190, 205 (D. Mass. 1998) ("It is similarly unlikely that the same Congress would in a single act [the Civil Rights Act ("CRA") of 1991] create a new constitutionally based right to a jury trial for Title VII plaintiffs, only to erode that right by endorsing mandatory pre-dispute arbitration agreements."), aff' $d, 170$ F.3d 1 (1st Cir. 1999). The language of the CRA of 1991 is of little assistance eitber. Section 118's language encourages arbitration while its legislative history states that the Act was not intended to permit mandatory arbitration. Jean R. Sternlight \& Michael Rubin, Part One: Major Ways of Challenging "Arbitration Agreements" in the Non-Unionized Employment Setting, 10 WORLD ARB. \& MEDIATION ReP. 249, 255 (1999).

27. A great deal of literature has concentrated on the shortcomings of the arbitration process itself (e.g., cost, speed, and bias of the arbitrator). Rather than focus on those shortcomings, this Comment addresses how the procedural differences between arbitration and litigation affect employees' rights and how applicants have little knowledge or understanding of these differences when they sign a PMAA. For articles addressing the shortcomings of arbitration more generally, see Jose A. Cabranes, Arbitration and U.S. Courts: Balancing Their Strengths, N.Y. ST. B.J. (Mar.-Apr. 1998); William L. Kandel, Mandatory Arbitration of Employment Claims, 591 PLI/LIT 901, 1000-04 (Oct./Nov. 1998); Panken et al., supra note 17, at 289-91; Cherry, supra note 6, at 276-86. For articles addressing efforts to improve due process in arbitration, such as the Due Process Protocol, see Lewis L. Maltby, Private Justice: Employment Arbitration and Civil Rights, 30 CoL. Hum. RTS L. Rev. 29, 45-46, 54 (1998); Prototype Agreement on Job Bias Dispute Resolution, DAILY LAB. RPT. (BNA), May 11, 1995, at D34.

28. Fitz, supra note 11, at 74-75. 
In other words, the arbitration context lacks the right to due process and extensive discovery needed to support one's claims. The U.S. Supreme Court summarized these limitations as follows:

[T] he factfinding process in arbitration usually is not equivalent to judicial factfinding. The record of the arbitration proceedings is not as complete; the usual rules of evidence do not apply; and rights and procedures common to civil trials, such as discovery, compulsory process, cross-examination, and testimony under oath, are often severely limited or unavailable. ${ }^{29}$

The rules of evidence in litigation can be particularly advantageous to employees. California, for example, limits the discovery and admissibility of evidence relatimg to a plaintiff's sexual history in judicial proceedings. ${ }^{30}$

The choice of forum can greatly affect an employee's chance of success as well. Juries tend to be more favorable to plaintiffs than arbitrators. "[1]n an area as personal and emotionally charged as sexual harassment and discrimination, the procedural right to a hearing before a jury of one's peers, rather than [an arbitrator], may be especially important." 31 A poll of typical jurors found that seventy percent of jurors were more likely to believe a terminated employee's version of events over a corporate employer's explanation before a hearing on the facts. ${ }^{32}$ Another poll showed that seventy-five percent of Americans believe that compamies were less loyal to their employees in the 1990s than in the $1980 \mathrm{~s} .{ }^{33}$ In court, these beliefs translate to a nearly sixty percent win rate for plaintiffs. ${ }^{34}$ On the other hand, win rates for plaintiffs in arbitration proceedings can be as low as thirty percent in discrimination cases. ${ }^{35}$

Furthermore, damage awards vary widely between trial and arbitration. Unlike courts and juries, which are more likely to adhere to the law, arbitrators are more likely to split the difference. ${ }^{36}$ The mean damages

29. Alexander v. Gardner-Denver Co., 415 U.S. 36, 57-58 (1974) (citations omitted). See also Litaker v. Lehman Bros. Holdings, Inc., No. 97-CIV-1607(DC), 1999 WL 619638, at *3 (S.D.N.Y. Aug. 17, 1999) (stating that depositions are usually not permitted and motion practice is limited).

30. CaL. Evid. Code $\$ \$ 782,1106$ (2002); CAL. CIv. Proc. Code $\$ 2017$ (d) (2002).

31. Prudential Ins. Co. of Am. v. Lai, 42 F.3d 1299, 1305 (9th Cir. 1994).

32. Kramer et al., supra note 22, at 181 (citing a 1991 Wall Street Journal poll).

33. Id. (citing a $1995 \mathrm{New}$ York Times poll).

34. Id. at 182 (citing an eight-year study by Jury Research, Inc.).

35. See Kandel, supra note 27, 991-92 (citing NASD arbitrator study and comparing it to NYSE's plaintiff win rate of forty-two percent). See also Liz Halloran, Companies Develop Their Own Brand of Justice Forced Arbitration Keeps Grievances Out of Court, HaRTFord Courant, Mar. 8, 1999, at Main (A) (stating that at least seventy percent of arbitration decisions are made in favor of the employer). But cf. Maltby, supra note 27 (reporting various studies finding that employee win rates at arbitration are sixty-four percent, sixty-three percent, and fifty-one percent, and concluding that enployees prevail more often in arbitration than in court but recover more in court).

36. Armendariz v. Found. Health Psychcare Servs., Inc., 6 P.3d 669, 693 (Cal. 2000) (citing Robert Haig, Corporate Counsel's Guide: Legal Development Report on Cost-Effective Management of Corporate Litigation, 610 PLI/LIT. 177, 186-87 (1999)). 
awarded by arbitrators from 1993 to 1995 was $\$ 49,030$ compared to $\$ 530,611$ by district courts. ${ }^{37}$ The median jury award in discrimination and sexual harassment cases alone was $\$ 250,000$. $^{38}$ These figures result in employees' receiving a quarter of what they demand in arbitration, but seventy percent of what they demand in court. ${ }^{39}$ Part of the problem is that arbitrators rarely award punitive damages, even though they have the power to do so. ${ }^{40}$ In some arbitral forums, punitive damages are prohibited altogether. ${ }^{41}$ But punitive damages play a particularly critical role in employment cases because they are awarded more often in these cases than in any other type of lawsuit. ${ }^{42}$ According to one study, punitive damage awards averaged $\$ 2,689,033$ in employment cases from 1985 to $1994 .{ }^{43}$ These factors translate into severe disparities between anounts awarded by juries and arbitrators. ${ }^{44}$

One other critical difference between litigation and arbitration is that decisions made at arbitration are subject to a virtually foolproof standard of review. ${ }^{45}$ An arbitrator's decision can be overturned in court only if it displays "manifest disregard" 46 for the law or is otherwise subject to

37. Maltby, supra note 27, at 47. These figures are based on American Arbitration Association (AAA) employment arbitrations from 1993-95 and 1994 Federal District Court cases. Id. at 48. The district court cases involved statutory civil rights claims where the law provides emotional distress and punitive damages while many of the arbitration cases were contract claims with economic damages. Id. at 47-48. However, this should have little effect on the figures since arbitrators tend to split the difference and rarely award punitive damages when given the chance. See supra note 36 and accompanying text; Thomas J. Stipanowich, Punitive Damages and the Consumerization of Arbitration, 92 Nw. U. L. Rev. 1, 56 (1997).

38. Litigation: Jury Awards in Employment Bias Cases Grew By 286 Percent in '97, Study Shows, Emp. Pol. \& L. Dally (BNA), Mar. 16, 1999, at D-12. See also Litigation: Juries More Favorable than Judges in State Court, Survey Shows, Daily Lab. ReP. (BNA) No. 184, Sept. 23, 1999, at A-6 (median punitive damage award in discrimination cases is $\$ 259,000$ ).

39. Employees demanded $\$ 165,128$ in arbitration and $\$ 756,738$ in court. Maltby, supra note 27 , at 48 .

40. See Stipanowich, supra note 37; Sullivan, supra note 16, at 345.

41. New York does not always allow punitive damages to be awarded in arbitration. See Dean Witter Reynolds lnc. v. Trimble, 166 Misc. $2 d 40$ (N.Y. Sup. Ct. 1995); Merrill Lynch, Pierce, Fenner \& Smith, Inc., v. Cornell (N.Y. Sup. Ct. 1996), reported in N.Y.L.J., Feb. 15, 1996, at 28. See also Maltby, supra note 27, at 45 (citing study finding that only fifty percent of private arbitration systems expressly permit the arbitrator to award punitive damages).

42. Kramer et al., supra note 22, at 182. Punitive damages are awarded in addition to compensatory damages in thirty-four percent of discrimination cases and thirty-eight percent of sexual harassment cases. Litigation: Jury Awards in Employment Bias Cases Grew by 286 Percent in '97, Study Shows, Emp. Pol. \& L. Daily (BNA), Mar. 16, 1999, at D-12.

43. Rand Institute for Civil Justice, Punitive Damage Awards in Financial Injury Jury Verdicts, available at http://www.rand.org/publications/RB/RB9028 (last visited Mar. 8, 2002).

44. See Vail, supra note 7, at 71. This is due in part to the nature of discrimination claims, which often involve "personal and emotionally charged" issues. Prudential lns. Co. of Am. v. Lai, 42 F.3d 1299,1305 n.4 (9th Cir. 1994).

45. Arbitration awards are usually reviewed under the Uniform Arbitration Act or the Federal Arbitration Aet. Paul Peter Nicolai, Rethinking Employment Law Strategies, 56 Disp. REsol. J. 53, 62 (2002).

46. Wilko v. Swan, 346 U.S. 427, 436-37 (1953). 
corruption, fraud, or bias. ${ }^{47}$ As one scholar noted, the standard of review governing arbitration decisions is "virtually insurmountable" and such decisions will almost always stand, whether or not they are fair or true to the law. ${ }^{48}$ Therefore, einployees in arbitration are less likely to receive what they may be entitled to by law.

These disparities between arbitration and litigation-limited appeal, discovery, evidence, and damages as well as chances for success-make signing a PMAA a significant and important consideration. ${ }^{49}$ Early on, the Supreme Court recognized that "the choice of forums inevitably affects the scope of the substantive right to be vindicated." 50 It is to these cases that the next section turns.

\section{B. The Early Mandatory Arbitration Cases ${ }^{51}$}

The Supreine Court decided three mandatory arbitration cases that set the stage for the current controversy. In these landmark cases, the Court evinced a doctrinal shift from complete repudiation of mandatory arbitration clauses to widespread acceptance of thein.

In Alexander v. Gardner-Denver, ${ }^{52}$ decided in 1974, the Supreme Court unanimously held that a member of the Steelworkers' Union could pursue his racial discrimination claim im court despite an adverse arbitral ruling pursuant to a mandatory arbitration provision in a collective bargaining agreement. The Court held, "[W]e think it clear that there can be no prospective waiver of an employee's rights under Title VII," $" 53$ and further stated that "[i]n no event can the submission to arbitration of a claim ... constitute a binding waiver with respect to an employee's rights under Title VII." 54 The effects of this decision have been significant. For years, courts consistently applied the 1974 Gardner-Denver decision to permit employees with mandatory arbitration agreements to bring

47. See Bowles Fin. Group, Inc. v. Stifel, Nicolaus \& Co., 22 F.3d 1010, 1012 (10th Cir. 1994) (citing 9 U.S.C. $\$ 10(a)-(e)(1988)$, which covers general provisions (e.g., vacation, grounds, and rehearing) of arbitration).

48. Bret F. Randall, The History, Application, and Policy of the Judicially Created Standards of Review for Arbitration Awards, 1992 BYU L. Rev. 759, 767. But cf. Cole v. Burns Int'1 Sec. Servs., 105 F.3d 1465, 1486-87 (D.C. Cir. 1997) (stating that the inanifest disregard standard is sufficiently broad to ensure that the law has been properly interpreted and applied).

49. See Fitz, supra note 11, at 923, 935; Jeffrey W. Stempel, Reconsidering the Employment Contract Exclusion in Section I of the Federal Arbitration Act: Correcting the Judiciary's Failure of Statutory Vision, 2 J. DisP. Resol. 259, 300 n.217 (1991); Rowe, supra note 11, at 923.

50. Alexander v. Gardner-Denver Co., 415 U.S. 36, 56 (1974) (citation omitted).

51. For a more complete history on mandatory arbitration agreements, see Beth M. Primm, Comment, A Critical Look at the EEOC's Policy Against Mandatory Pre-Dispute Arbitration Agreements, 2 U. PA. J. LAB. \& EMP. L. 151 (1999) (discussing Wilko, American Safety, Scherk, and other applicable cases). For general history on arbitration, see Cole, supra note 8.

52. 415 U.S. 36 (1974).

53. Id. at 51 .

54. Id. at 52 n.15. 
independent statutory claims against their employers. ${ }^{55}$ This resulted in a significant increase in civil cases which flooded the federal courts. ${ }^{56}$

Faced with an increased workload, the courts attempted to clear their dockets by "shak[ing] off the old judicial hostility to arbitration."57 The first decision to reflect this doctrinal change was Mitsubishi Motors Corp. v. Soler Chrysler-Plymouth, Inc. ${ }^{58}$ where thc Court relied on the FAA and its "liberal federal policy favoring arbitration agreements" 59 and held that "[b]y agreeing to arbitrate a statutory claim, a party does not forego the substantive rights afforded by the statute; it only submits to their resolution in an arbitral, rather than a judicial, forum." ${ }^{\circ 0}$ In so holding, the Court created a new presumption that unless Congress has shown an intention to preclude a waiver of judicial remedies, the party should be held to the mandatory arbitration agreement. ${ }^{61}$ Although this case was in a business context rather than a civil rights context, it was clear that the Supreme Court was beginning to view mandatory arbitration agreements as voluntary contracts between parties. ${ }^{62}$

In 1991, Gilmer v. Interstate/Johnson Lane Corp. ${ }^{63}$ solidified Mitsubishi's presumption in favor of mandatory arbitration. In Gilmer, the

55. Sullivan, supra note 16, at 320. See, e.g., Alford v. Dean Witter Reynolds, Inc., 905 F.2d 104, 105-08 (5th Cir. 1990); Utley v. Goldman Sachs \& Co., 883 F.2d 184, 185-87 (1 st Cir. 1989); Swenson v. Mgmt. Recruiters Int'l, Inc., 858 F.2d 1304, 1305-07 (8th Cir. 1988); Rosenfeld v. Dep't of the Army, 769 F.2d 237, 239 (4th Cir. 1985); EEOC v. Children's Hosp. Med. Ctr., 719 F.2d 1426, 1431 (9th Cir. 1983) (en banc) (Fletcher, J., concurring).

56. Cole, supra note 8, at 449; Estreicher, supra note 11, at 1372.

57. Mitsubishi Motors Corp. v. Soler Chrysler-Plymouth, Inc., 473 U.S. 614, 638 (1985) (citing Kulukundis Shipping Co. v. Amtorg Trading Corp., 126 F.2d 978, 985 (2d Cir. 1942)).

58. 473 U.S. 614 (1985). Two other significant cases, which together with Mitsubishi are referred to as the "Mitsubishi Trilogy," are Shearson/American Express, Inc. v. McMahon, 482 U.S. 220 (1987) (extending the Mitsubishi holding to complaints under the Racketeer Influenced and Corrupt Organizations Act (RICO) and holding that the party opposing arbitration has the burden of showing that Congress intended to preclude a waiver), and Rodriguez de Quijas v. Shearson/American Express, Inc., 490 U.S. 477 (1989) (enforcing an agreement to arbitrate a statutory claim under the Securities Exchange Act of 1933).

59. Mitsubishi, 473 U.S. at 625 (citing Moses H. Cone Mem'l Hosp. v. Mercury Constr. Corp., 460 U.S. 1, 24 (1983)). Congress and President Coolidge enacted the FAA in 1925, nearly fifty years before the Supreme Court's holding in Gardner-Denver, yet Gardner-Denver did not address the Act or its applicability to the case. At that time, the Supreme Court seemed to ignore the FAA's goal of "revers[ing] the longstanding judicial hostility to arbitration agreements that had existed at English common law and has been adopted by Ameriean courts ... ." Gilmer v. Interstate/Johnson Lane Corp., 500 U.S. 20, 24 (1991) (citing Dean Witter Reynolds, Inc. v. Byrd, 470 U.S. 213, 219-20 \& n.6 (1985)). See Estreieher, supra note 11, at 1372 ("[T]he caseload and 'litigation explosion' considerations ... implicitly prompted the Court in the first place to find in the FAA a broadly preemptive pro-arbitration sword ....").

60. Mitsubishi, 473 U.S. at 628.

61. Id.

62. "“[The] preeminent concern of Congress in passing the [FAA] was to enforce private agreements into which parties had entered, a concern which 'requires that we rigorously enforce agreements to arbitrate."'Mitsubushi, 473 U.S. at 625-26 (citing Dean Witter, 470 U.S. at 221).

63. 500 U.S. $20(1991)$. 
plaintiff was required, as a condition of employment with a brokerage firm, to register with a stock exchange whose employment agreement compelled submitting any dispute, claim, or controversy that arose out of the employment context to mandatory binding arbitration. Although the plaintiff signed the agreement, he later filed an age discrimination claim under the ADEA with the Equal Employment Opportunity Commission ("EEOC") instead of submitting the matter to arbitration. The Court, consistent with Mitsubishi, granted defendant's motion to compel arbitration.

The Court reconciled its divergent holdings in Gardner-Denver and Mitsubishi by stating, "The Court in [Gardner-Denver] also expressed the view that arbitration was inferior to the judicial process for resolving statutory claims. That 'mistrust of the arbitral process,' however, has been undermined by our recent arbitration decisions." In so holding, the Court neither overruled Gardner-Denver nor provided a rationale for the rejection of its prior stand against mandatory arbitration other than citing the FAA's liberal policy favoring arbitration agreements. ${ }^{65}$ The Supreme Court did leave open the possibility, however, that PMAAs may be unenforceable as to certain statutory claims, but so far has not rendered any statutory claim exempt from mandatory arbitration. ${ }^{66}$ To this day, it continues to fully embrace mandatory arbitration. ${ }^{67}$

\section{The Current State of the Law}

Since Gilmer, PMAAs have been a source of controversy in all three branches of the government. It is critical to understand the current legal landscape surrounding PMAAs, particularly since the area is complex and continuously changing. The following section summarizes the current state of the law by examining PMAAs from the perspective of the three branches of government.

\section{Judicial Review of PMAAs}

Gilmer's presumption in favor of mandatory arbitration remams the current state of the law. Prior to Gilmer, a majority of courts refused to

64. Id. at 34 n.5 (citations omitted).

65. Id. at 35 (citation omitted).

66. The Court noted:

'The party should be held to [the PMAA] unless Congress itself has evimced an intention to preclude a waiver of judicial remedies for the statutory rights at issue' .... If such an intention exists, it will be discoverable in the text of the [statute], its legislative history, or an 'inherent conflict' between arbitration and the [statute's] underlying purposes. Id. at 26 (citation onitted).

67. The Supreme Court's pro-arbitration stance evokes strong criticism. See Paul D. Carrington \& Paul H. Haagen, Contract and Jurisdiction, 1996 Sup. CT. REv. 331, 401 ("As architecture, the arbitration law made by the [Supreme Court] is a shantytown. It fails to shelter those who most need shelter. And those it is intended to shelter are ill-housed."). 
enforce PMAAs. ${ }^{68}$ Following Gilmer, however, courts have uniformly enforced PMAAs under such statutes as Title VII, the ADA, the ADEA, the Family Medical Leave Act ("FMLA"), the Equal Pay Act ("EPA"), and Section $1981 .^{69}$ These courts use a number of standards to review the enforceability of PMAAs: the knowing and voluntary standard, the appropriate standard, and the contractual standard. ${ }^{70}$

\section{a. The Knowing and Voluntary Standard}

The standard generally applied to waivers of constitutional and statutory rights, including the right to a jury trial, is knowing and voluntary consent. ${ }^{71}$ The question then arises whether waivers of the right to a jury trial

68. See Cherry, supra note 6, at 271. See also cases cited supra note 55.

69. The Ninth Circuit, however, recently held in Duffield v. Robertson that PMAAs are unenforceable as a matter of law. 144 F.3d 1182 (9th Cir. 1998), cert. denied, 525 U.S. 982 (1998). Only a few district courts outside the Ninth Circuit agree. See Martens v. Smith Barney, lnc., 181 F.R.D. 243 (S.D.N.Y. 1998); Winkler v. Pac. Brokerage Servs., Inc., No. 97-C-7340, 1998 U.S. Dist. LEXIS 9236 (N.D. 1ll. 1998); O'Hara v. Mt. Vernon Bd. of Educ., 16 F. Supp. 2d 868 (S.D. Ohio 1998). Most other courts emphatically disagree with the Ninth Circuit's reasoning. See Desiderio v. Nat'l Ass'n of Sec. Dealers, lnc., 191 F.3d 198 (2d Cir. 1999); Seus v. John Nuveen \& Co., 146 F.3d 175 (3d Cir. 1998), cert. denied, 525 U.S. 1139 (1999); Mouton v. Metro. Life lns. Co., 147 F.3d 453 (5th Cir. 1998); Great Westcrn Mortgage Co. v. Peacock, 110 F.3d 222 (3d Cir. 1997); Metz v. Merrill Lynch, Pierce, Fenner \& Smith, Inc., 39 F.3d 1482 (10th Cir. 1994); Willis v. Dean Wittcr Reynolds, Inc., 948 F.2d 305 (6th Cir. 1991); see also Koveleskie v. SBC Capital Mkts., Inc., 167 F.3d 361 (7th Cir. 1999) (noting clear congressional intent to encourage mandatory arbitration agreements). Some courts refuse to enforce PMAAs, but not because they find PMAAs unenforceable as a matter of law. See Rosenberg v. Merrill Lynch, Pierce, Fenner \& Smith, Inc., 170 F.3d 1 (1st Cir. 1999) (refusing to enforce arbitration agreements where there is arbitrator bias or inadequate notice of arbitration); Shankle v. B-G Maint. Mgmt. of Colo., Inc., 163 F.3d 1230 (10th Cir. 1999) (refusing to enforce arbitration agreement where employee had to pay half of arbitrator's fee); Paladino v. Avnet Computer Techs., 134 F.3d 1054 (11th Cir. 1998) (refusing to enforce arbitration agreement where arbitrator limited remedies to contractual damages); Patterson v. Tenet Healthcare, Inc., 113 F.3d 832 (8th Cir. 1997) (implying that arbitration agreements will not be enforced if process is not neutral or employee is denied adequate relief or discovery); Cole v. Burns Int'l Sec. Servs., 105 F.3d 1465 (D.C. Cir. 1997) (holding that Title VII discrimination claim is arbitrable so long as employer pays cost and there is meaningful appeal).

70. These standards were summarized by the Sixth Circuit in Haskins v. Prudential Ins. Co. of $A m ., 230$ F.3d 23I, 235-38 (2000).

71. See D.H. Overmeyer Co. v. Frick Co., 405 U.S. 174, 185-86 (1972) (stating that waiver of due process rights must be "voluntary, knowing, and intelligently made"); Leasing Serv. v. Crane, 804 F.2d 828, 832-33 (4th Cir. 1986) (stating that waiver of right to jury trial under Seventh Amendment must be "knowingly and intentionally"); KMC v. Irving Trnst, 757 F.2d 752, 756 (6th Cir. 1985) (noting that most courts require that waivers of the right to a jury trial be "knowing and voluntary"); Nat'l Equip. Rental, Ltd. v. Hendrix, 565 F.2d 255, 258 (2d Cir. 1977) (stating that relinquishment of right to jury trial under the Seventh Amendment must be made "knowingly and intentionally"); Dreiling v. Peugeot Motors of Am., Inc., 539 F. Supp. 402, 403 (D. Colo. 1982) (stating that waiver of right to jury trial under the Seventh Amendment must be made "knowingly, voluntarily and intentionally"); See also Alexander v. Gardner-Denver Co., 415 U.S. 36, 52 n.15 (1974) (stating that waiver of Title Vll claims must be "voluntary and knowing"); Puentes v. United Parcel Serv. Inc., 86 F.3d 196, 198 (11th Cir. 1996) (referencing the "knowing and voluntary" standard for Title VII and 42 U.S.C. $\S 1981$ releases of liability); Pierce v. Atchison, Topeka \& Santa Fe Ry. Co, 65 F.3d 562, 571 (7th Cir. 1995) (requiring releases of liability for age discrimination claims be "knowing and voluntary"); Torrez v. Pub. Serv. Co. of N.M., 908 F.2d 687, 689 (10th Cir. 1990) (requiring that 
in PMAAs require knowing and voluntary consent. ${ }^{72}$ The Supreme Court has not expressly decided whether PMAAs require a heightened standard of consent, but the Court did use the "knowing and voluntary" language in Gardner-Denver when it noted that "[i]n determining the effectiveness of any such waiver, a court would have to determine at the outset that the employee's consent to the settlement was voluntary and knowing." ${ }^{.73}$ This dicta has not been seized by the courts and uniformly transferred to the PMAA context. At least one court, however, has utilized the knowing and voluntary language.

The Ninth Circuit held in Prudential Insurance Co. v. Lai that in order for an employee to waive his rights to a judicial forum in favor of mandatory arbitration, consent must be knowing and voluntary. ${ }^{74}$ Although the Lai court did not specifically define "knowing and voluntary," it examined the language of the arbitration agreement, the employee's awareness of the agreement, and the employee's understanding of what the agreement required. Applying this standard to the facts of the case, the court held that the employee did not knowingly agree to arbitrate because the securities exchange registration form that the employee was required to sign as a condition of employment did not describe the types of disputes subject to arbitration. ${ }^{75}$

Apart from Lai, however, this knowing and voluntary consent standard "has been rejected by nearly every court that has had an opportunity to pass upon it, ${ }^{376}$ although there are a few lower courts that have followed

release of Title VII and Section 1981 discrimination claims upon termination be "knowing and voluntary").

72. Hooters of Am., Inc. v. Phillips, 39 F. Supp. 2d 582, 611 (D.S.C. 1998) (“[B]ecause Title VII now requires a jury trial, there is a serious question whether the rights at stake are constitutionally based, underscoring the need for a 'knowing and voluntary' standard for the waiver of such rights.") (citations oinitted).

73. Gardner-Denver, 415 U.S. at 52 n.15.

74. 42 F.3d 1299, 1305 (9th Cir. 1994). The Ninth Circuit did not specifically use the word "voluntary" im this case. However, the court relied on Gardner-Denver, which used the "knowing and voluntary" language, and Senator Dole's statement that arbitration is encouraged only "where the parties knowingly and voluntarily elect to use these methods." Id. at 1304-05. A few years later in Nelson v. Cyprus Bagdad Copper Corp., 119 F.3d 756, 761 n.10 (9th Cir. 1997), the court noted that its decision in Lai suggested that enployee consent to PMAAs must be both "knowing and voluntary," but declined to determine whether a PMAA must also be voluntary since the agreement at issue already failed the knowing requirement. $C f$. Kummetz v. Tech Mold, Inc., 152 F.3d 1153 (9th Cir. 1998) (referring to "knowing" but not "voluntary" waivers); Renteria v. Prudential Ins. Co., 113 F.3d 1104, 1108 (9th Cir. 1997) (same).

75. 42 F.3d at 1305 .

76. Haskins, 230 F.3d 231, 239-40. See also Seus v. John Nuveen \& Co., Inc., 146 F.3d 175 (3d Cir. 1998); Patterson v. Tenet Healthcare, Inc., 113 F.3d 832 (8th Cir. 1997); Beauchamp v. Great West Life Assurance Co., 918 F. Supp. 1091 (E.D. Mich. 1996); DeCaminada v. Coopers \& Lybrand, LLP, 591 N.W.2d 364 (Mich. App. 1999). But see Ramirez-de-Arellano v. Am. Airlines, Inc., 133 F.3d 89, 90 (1st Cir. 1997) (holding that arbitration agreement must be "voluntary and intentional" in action brought under Fair Labor Standards Act ("FLSA") and Puerto Rico law). Ramirez-de-Arellano relies on Mitsubishi to support this standard. Id. (citing Mitsubishi, 473 U.S. 614, 626 (1985)). However, a close 
the Ninth Circuit's lead. ${ }^{77}$ The Ninth Circuit has recently set yet another standard by changing its position on PMAAs from weary acceptance to strict unenforcement of such agreements. ${ }^{78}$

\section{b. The Appropriate Standard}

The appropriate standard derives its name directly froin language in Section 118 of the Civil Rights Act of 1991, which states, "Where appropriate and to the extent authorized by law ... arbitration... is encouraged to resolve disputes." 79 This standard was first applied in Rosenberg v. Merrill Lynch. ${ }^{80}$ In Rosenberg, the plaintiff was required to register with the NASD or the NYSE and complete a U-4 form, a securities exchange registration form containing a mandatory arbitration clause, in order to gain employment. Relying on Section 118's language, the First Circuit ruled that the PMAA was inappropriate under the circumstances because the employer never provided the plaintiff with a copy of the NASD or NYSE rules, and furthermore, had failed to familiarize the plaimtiff with the arbitration procedure, as required by the rules. ${ }^{81}$

The First Circuit's appropriate test amounts to a notice standard. ${ }^{82}$ There needs to be a sufficient level of notice before the First Circuit will uphold the arbitration agreement as appropriate. However, the First Circuit noted that had the employer made a modest effort to make the relevant information available to the employee, then it would have compelled arbitration. ${ }^{83}$ The First Circuit's notice requirement is therefore rather minimal.

examination of Mitsubishi yields no support for this standard. In fact, the Court's reasoning impliedly favors using a contractual standard to examine arbitration agreements. Mitsubishi, 473 U.S. 614, 627 (1985) ("[A]bsent such compelling [contractl considerations, the Act itself provides no basis for disfavoring agrcements to arbitrate statutory claims.").

77. Hooters of Am., Inc. v. Phillips, 39 F. Supp. 2d 582, 612 (D.S.C. I998) ("knowing and voluntary"); Trumbull v. Century Mktg. Corp., 12 F. Supp. 2d 683 (N.D. Ohio 1998) ("knowing"); Hoffman v. Aaron Kamhi, Inc., 927 F. Supp. 640 (S.D.N.Y. 1996) ("knowing").

78. See Duffield v. Robertson, I44 F.3d I182 (9th Cir. 1998), cert. denied, 525 U.S. 982 (1998).

79. Pub. L. No. I02-166, $\S 118,105$ Stat. 1071, 1081 (1991). The appropriate standard is a specific interpretation of this language in Section I18. The First Circuit interprets "appropriate" to mean minimal notice. See Rosenberg v. Merrill Lynch, Pierce, Fenner \& Sinith, Inc., 170 F.3d 1, 21 (Ist Cir. 1999). In contrast, the Ninth Circuit in Lai interprets "appropriate" to mean "knowingly." Prudential Ins. Co. of Am. v. Lai, 42 F.3d 1299, 1305 (9th Cir. 1994).

80. 170 F.3d 1 (1st Cir. 1999).

81. Although the Court acknowledged Lai's knowing and voluntary standard, it found it unnecessary to consider this issue because Section 118 does not contain the words "knowing and voluntary." Id. at 18. However, the First Circuit did find that an agreeinent to arbitrate must be "voluntary and intentional" in an action brought under the FLSA and Puerto Rico law. Ramirez-deArellano, 133 F.3d at 90.

82. Rosenberg, 170 F.3d at 21 ("[T/here [must] be some minimum level of notice to the cinployee that statutory claims are subject to arbitration.").

83. Id. 
A few courts have followed the Rosenberg standard of review, even though not all of them have referred to it as the "appropriate" test. ${ }^{84}$ Many more courts, however, have either explicitly or implicitly rejected the Rosenberg standard. Courts refusing to follow Rosenberg have held that the burden is on the employee to read the arbitration agreement and to understand its content as well as its import. ${ }^{85}$ For example, the Sixth Circuit in Haskins v. Prudential Insurance Co. found that the arbitration clause in the U-4 form was sufficient notice to the plaimtiff. ${ }^{86}$ The court stated, "If [the plaintiff] 'did not make herself aware of the existence or scope of [the arbitration] clause [in the U-4 agreement], she did so at her own peril.' She is 'presumed to know the contents of the signed agreement' as well as its reasonable import." ${ }^{87}$ Courts like Haskins concentrate not on notice but rather on whether contractual standards are being met.

\section{c. The Contractual Standard}

The remaining courts that enforce PMAAs apply the contractual standard, which voids arbitration clauses or agreements only if they run contrary to ordinary contract principles such as fraud, duress, or unconscionability. ${ }^{88}$ For example, in Seus v. John Nuveen \& Co., Inc. ${ }^{89}$ the Third Circuit stated that "[n]othing short of a showing of fraud, duress, mistake or some other ground recognized by the law of contracts generally would have excused the district court from enforcing Seus's [mandatory arbitration] agreement." ${ }^{\text {"90 }}$ Similarly, in Haskins, the Sixth Circuit examined the various standards used by courts to determine the enforceability of PMAAs and found the contractual standard to be superior "because it does not plainly ignore long-standing rules of contract law." courts have also adopted the contractual standard. ${ }^{92}$ Although the Supreme

84. See DeLuca v. Bear Stearns \& Co., 175 F. Supp. 2 d 102 (D. Mass 2001) (examining whether enforcement of the arbitration agreenent was appropriate); Klinedinst v. Tiger Drylac, U.S.A., Inc., 01CV040, 2001 WL 1561821 (D.N.H. 2001) (examining whether there was sufficient notice of the arbitration agreement but not referring to an appropriate standard).

85. Haskins v. Prudential Ins. Co. of Am., 230 F.3d 231, 237 (6th Cir. 2000) (citing Rosenberg, 170 F.3d at 18-19); Ludwig v. Equitable Life Assurance Soc'y of the U.S., 978 F. Supp. 1379, 1382 (D. Kan. 1997); Herko v. Metro. Life Ins. Co., 978 F. Supp. 141, 147 (W.D.N.Y. 1997).

86. Haskins, 230 F.3d at 241 .

87. Id. at 240-41 (citmg concurring and dissenting opinion im Rosenberg, $170 \mathrm{~F} .3 \mathrm{~d}$ at 23).

88. Doctor's Assocs., Inc. v. Casarotto, 517 U.S. 681, 686-87 (1996).

89. 146 F.3d 175 (3d Cir. 1998).

90. Id. at 184 .

91. Haskins, 230 F.3d at 239.

92. See Patterson v. Tenet Healthcare, Inc., 113 F.3d 832 (8th Cir. 1997) (stating that ordinary contract principles govern whether parties have agreed to arbitrate); Beauchamp v. Great West Life Assurance Co., 918 F. Supp. 1091 (E.D. Mich. 1996) (holding that a party is generally chargeable with knowledge of the existence and scope of an arbitration clause in the absence of fraud, deception, or other misconduct that excuses lack of knowledge); DeCaminada v. Coopers \& Lybrand, LLP, 591 N.W.2d 364, 367-68 (Mich. App. 1999) (holding that arbitration clause "shall be valid, irrevocable, and enforceable, save upon such grounds as exist at law or in equity for the revocation of any contract"). 
Court has not delineated any specific standard to examine PMAAs, it has stated that "generally applicable contract defenses, such as fraud, duress, or unconscionability, may be applied to invalidate arbitration agreements." ${ }^{\prime \prime 3}$

\section{Executive Response to PMAAs}

Federal Commissions and agencies have taken strong positions against PMAAs. In 1993, the Secretaries of Labor and Commerce established the Commission on the Future of Worker-Management Relations ("Dunlop Commission") to report on a number of questions regarding employee relations. After extensive research, the Dunlop Commission concluded that PMAAs should not be enforced. ${ }^{94}$ The Committee stated, "Employees required to accept binding arbitration ... would face what for many would be an inappropriate choice: give up your right to go to court, or give up your job." $" 95$ The Commission urged courts to interpret the FAA as prohibiting pre-dispute mandatory arbitration and, in the event that failed, recommended legislation that allowed employees to choose among alternative methods of resolving disputes. ${ }^{96}$ The Secretary of Labor's Task Force on Excellence in State and Local Government through LaborManagement Cooperation, responsible for examining labor-management cooperation in state and local government, came to the same conclusion in 1996. It recommended that all employee arbitration agreements be voluntary and entered into after the initiation of a dispute. ${ }^{97}$

Agencies have also been vocal in this controversy. One agency in particular, the EEOC, has strongly argued for the abolition of PMAAs since 1995. It opposes mandatory arbitration of employment discrimination claims that are required as preconditions of employment or that attempt to

Some scholars have also argued that voluntary consent of PMAAs can be established through basic contractual principles. See, e.g., Samuel Estreicher, Predispute Agreements to Arbitrate Statutory Employment Claims, 72 N.Y.U. L. Rev. 1344, 1358 (1997); Stephen J. Ware, Employment Arbitration and Voluntary Consent, 25 HoFstra L. Rev. 83 (1996).

93. Casarotto, 517 U.S. at 681.

94. However, the Commission sheds little light on its reasons for finding PMAAs unacceptable. Manuszak, supra note 9, at 421 . The Dunlop Commission focused its efforts primarily on improving the arbitration process itself. It recommended that arbitration include: (1) a neutral arbitrator who knows the law in question; (2) a fair and simple method by which an employee can secure the necessary information to present his or her claims; (3) a fair method of cost-sharing between the employer and employee to ensure affordable access to the system for all employees; (4) a range of remedies equal to those available through legislation; (5) a written opinion by the arbitrator explaining the rationale for the result; and (6) sufficient judicial review to ensure that the result is consistent with the governing laws. The Dunlop COMmission on the Future of Worker-Management RELATIONS: FINAL REPORT 56-57 (1993-94), available at http://ilr.comell.edu/library/e_archive/ gov_reports/dunlop/DunlopFinalReport.pdf [hereinafter THE DUNLOP REPORT].

95. THE DUNLOP REPORT, supra note 94 , at 59.

96. Id.

97. Task Force on Excellence in State and Local Government Through LaborManagement CoOperation, Working Together for Public Service 94-95 (1996), available at http:/ilir.cornell.edu/library/e_archive/gov_reports/labor_nanagement/WorkingTogether.pdf. 
prevent individuals from filing an EEOC charge..$^{98}$ It maintains that waivers required as conditions of employment before a dispute even arises can never be knowing and voluntary. ${ }^{99}$ In 1996 , the EEOC declared that its second highest priority would be unsettled questions of law, such as predispute mandatory arbitration. ${ }^{100}$

Although the EEOC does not have legislative power, ${ }^{101}$ it does have the power to decide discrimination claims that are filed with the Commission. Such powers have been used to promote the EEOC's views on PMAAs and have been upheld by the courts. For example, in EEOC $v$. River Oaks Imaging and Diagnostic, ${ }^{102}$ the EEOC successfully brought suit against an employer, alleging that the mandatory arbitration agreeinent was so misleading that it violated the Civil Rights Act of 1964. The employer required its employees to sign a PMAA after seventeen of its employees filed discrimmation claims against the company. Einployees who refused to sign the agreement were fired. The EEOC argued that the PMAA violated the employees' statutory rights under Title VII and that Congress intended to encourage only voluntary arbitration when it passed the Civil Rights Act of 1964. A prelimmary injunction was ordered against the agreement and in response the company dismantled it. The EEOC has shown that "[it] can and will bring litigation against employers implementing [PMAAs]."103

The National Labor Relations Board ("NLRB") has also voiced opposition to PMAAs and has taken the position that mandatory arbitration agreements in nonunion contexts violate the National Labor Relations Act ("NLRA"). ${ }^{104}$ In 1995, the NLRB instigated proceedings for unfair labor practices against Bentley's Luggage Corp. after Bentley's fired an

98. The EEOC recently won a large victory when the Supreme Court ruled that arbitration agreements do not bar the EEOC from pursuing victim-specific relief on behalf of employees. EEOC $v$. Waffle House, Inc., 534 U.S. 279 (2002). Since the EEOC is not a party to PMAAs, it can use its independent statutory authority to seek relief im court. Id. at 764. Although the EEOC pursues victimspecific relief in such cases, it also vindicates a public interest in preventing discrimmation. Id. at 765 . However, any recovery an employee obtains from a settlement or arbitral award limits the EEOC's awvard accordingly. Id. at 765-66.

99. See generally EEOC Policy Statement, supra note 7. The American Bar Association, Aunerican Medical Association, and American Arbitration Association also express the view that waivers of rights in mandatory arbitration agreeinents can never be knowing and voluntary. Vail, supra note 7, at 70. Even the National Academy of Arbitrators opposes mandatory and binding arbitration. National Academy of Arbitrators' Statement and Guidelines, DaILy LAB. REP. (BNA) No. 103, May 29 , 1997, at E-1.

100. EEOC Position on ADR Criticized, DaILY LAB. REP. (BNA) No. 61, Mar. 29, 1996, at C-2-3.

101. The EEOC can create regulations, but Congress can bar or abort them.

102. 67 F.E.P. (BNA) 1243 (S.D. Tex. 1995).

103. Fitz, supra note 11 , at 77.

104. Bentley's Luggage Corp., Dally LAB. Rep. (BNA) No. 96 (May-June 1996 \& Supp.), May 17, 1996, at A-11 (describing the outcoine of Bentley's Luggage Corp., NLRB, 12-CA-16658 (May 16, 1996)). See Ann C. Hodges, Arbitration of Statutory Claims in the Unionized Workplace: Is Bargaining with the Union Required?, 16 OHIO ST. J. ON DisP. Resol. 513, 541-44 (2001). 
employee for not signing a mandatory arbitration agreement. The Board reasoned that the mandatory arbitration agreement precluded the NLRB's enforcement of the NLRA because, unlike the EEOC, the NLRB cannot initiate its own suits and can only enforce the NLRA after a charge has been filed. The case ultimately settled, with the employer agreeing to dismantle the mandatory arbitration agreement. Although the Board's opposition to PMAAs seems to have waned recently, ${ }^{105}$ it has stated that it will continue to pursue cases where arbitration agreements interfere with the Board's authority to remedy unfair labor practice charges under the NLRA. ${ }^{106}$

\section{Legislative Response to PMAAs}

Members of Congress are mostly concerned with the involuntary nature of PMAAs. Unlike the courts, however, some legislators believe that the problem of voluntariness cannot be remedied through legal standards at all. They argue that PMAAs should be entirely unenforceable. Several bills currently pending would abolish pre-dispute mandatory arbitration agreements. For example, the Civil Rights Procedures Protection Act of 2001, ${ }^{107}$ introduced in the current Congress, would amend the FAA and major employment discrimination statutes ${ }^{108}$ to permit arbitration only if an employee voluntarily agrees to submit a dispute to arbitration after the dispute arises. Another bill, the National Employment Dispute Resolution Act of $2001,{ }^{109}$ demonstrates a more subtle disapproval of PMAAs by proposing to amend employment discrimination statutes to encourage mediation

105. In a 1997 settlement with Raytheon, E-Systems Greenville Division, the NLRB required only that the company revise its mandatory arbitration policy to make it clear that employees still have access to the NLRB. Several other charges have been filed about mandatory arbitration, but the Board has not adjudicated any of these cases. Tanya A. Yatsco, Comment, How About a Real Answer? Mandatory Arbitration as a Condition of Employment and the National Labor Relations Board's Stance, 62 ALB. L. REV. 257, 277 (1998).

106. See Morton H. Orenstein, Mandatory Arbitration: Alive and Well or Withering on the Vine?, 54 Disp. Resol. J. 57, 86 (1999).

107. The bill, S. 163, was referred to the Senate Committee on Health, Education, Labor, and Pensions on January 24, 2001. One or more of the sponsoring Senators introduced this same bill in other sessions but without success. See S. 121, H.R. 872, 106th Cong. (1999) (referred to the Senate Committee on Health, Education, Labor, and Pensions and House subcommittee); S. 63, H.R. 983, 105th Cong. (1997) (referred to Senate Committee on Labor and Human Resources and House subcommittees); S. 366, 104th Cong. (1995), H.R. 3748, 104th Cong. (1996) (same); S. 2405, H.R. 4981, 103d Cong. (1994) (same).

108. These employment discrimination statutes include Title VII, the Rehabilitation Act of 1973, the ADA, the ADEA, 42 U.S.C. $\$ 1981$, the EPA, and the FMLA.

109. H.R. 820, 107th Cong. (2001). The bill was referred to a House subcommittee on April 30 , 2001. Similar to the Civil Rights Protections Proeedure Act, this proposed legislation has been introduced a number of times without suecess. See H.R. 4593, 106th Cong. (2000) (referred to House subcommittee); S. 2327, 103d Cong. (1994), H.R. 2016, 103d Cong. (1993) (referred to Senate Committee on Labor and Human Resources and House subcommittees); S. 3356, H.R. 6197, 102d Cong. (1992) (same). 
rather than arbitration. Despite nearly a decade of efforts, no federal bill regarding PMAAs has passed in any context, ${ }^{110}$ including employment. ${ }^{111}$

While Congress has failed to make much progress in this area, soine state legislators are seeking to provide a solution to the controversy over PMAAs, notwithstanding questions regarding the validity of state action under the FAA. ${ }^{112}$ California has been particularly activc on this front. In 1999, California legislators drafted legislation that explicitly prohibited employers from requiring, or even requesting, that employees waive certam rights as a condition of employment, such as the right to a jury trial and other civil rights under federal and state anti-discrimination statutes. ${ }^{113}$ Although the final draft of the bill that passed had nothing to do with mandatory arbitration, ${ }^{114}$ other bills that have been introduced since would make it illegal for companies to force einployees to arbitrate state employinent law claims under the Fair Employment and Housing Act and that would prohibit mandatory arbitration in the health care industry. ${ }^{115}$

$$
* * *
$$

Regardless of the branch of government, there is growing opposition to PMAAs. Efforts by the legislature and executive agencies and commissions to abolish PMAAs, however, have been mostly unsuccessful. The greatest success so far has been efforts by some courts to instill a knowing and voluntary standard of consent to these agreements. A heightened standard of consent seems to be an ideal compromise, but a closer look demonstrates that this solution is troublesome at best.

110. See, e.g., Consumer Credit Fair Dispute Resolution Act of 2000, S. 2117, 106th Cong. (2000) (prohibiting arbitration in consumer credit transactions unless the parties voluntarily agree to arbitration after a dispute arises); The American Homebuyer's Protection Act, H.R. 5033, 106th Cong. (2000) (prohibiting purchasers from having to consent to a mandatory arbitration agreement as a condition precedent to entering into a homebuilding purchase contract); Motor Vehicle Franchise Contract Arbitration Fairness Act of 1999, H.R. 534, S. 1020, 106th Cong. (1999) (giving parties to a motor vehicle franchise contract the option, after a controversy arises and before both parties commence an arbitration proceeding, to reject arbitration as the means of settling the controversy); Consumer Fairness Act of 1999, H.R. 2258, 106th Cong. (1999) (treating arbitration clauses, which are unilaterally imposed on consumers, as an unfair and deceptive trade practice and prohibiting their use in consumer transactions).

111. For example, in the 103d Congress (1993-94), Senator Feingold introduced the Protection from Coercive Employment Agreements Act, which would have amended the Civil Rights Act of 1964 and other civil rights laws to prohibit employers from requiring employees to subınit employment discrimination claims to mandatory arbitration. S. 2012, 103d Cong. (1994) (last referred to the Senate Coinmittee on Labor and Human Resources on April 13, 1994).

112. See infra Part IV.E.

113. Michael Peabody, Eliminating the Mandatory Trade-Off: Should Employees Have the Right to Choose Arbitration?, 1 PEPP. DiSP. REsol. L.J. 107 (2000). An employer who violated the statute would have been subject to a $\$ 5000$ fine for each violation. Id. at 110 .

114. See A.B. 858 in the 1999 congressional session, available at http://www.sen.ca.gov.

115. Kevin Livingston, Taking on Arbitration, THE RECORDER, Mar. 12, 2002, at 1. 
II

\section{BARRIERS TO ACHIEVING KNOWING AND VOLUNTARY CONSENT}

Since both courts ${ }^{116}$ and scholars ${ }^{117}$ support a knowing and voluntary standard of consent, it is worth examining this recommendation carefully. When doing so, it is clear that a knowing and voluntary standard of consent is a worthwhile goal, but caunot presently be achieved. First, it is not clear what "knowing and voluntary" means. Courts have failed to adequately define these terms, and scholars have differing ideas on what the standard requires. ${ }^{118}$ Second, applicants face a number of human shortcomings, such as faulty notions of legal protection and human errors in judgment. Third, it is difficult to even conceive of a truly voluntary standard in the PMAA context when applicants have no choice but to sign the agreement if they want employment. This next section explores these limitations.

\section{A. The Elusive Meaning of "Knowing and Voluntary"}

The first problem with implementing the knowing and voluntary standard in the pre-employment context is that no court has explicitly defined the terms "knowing" and "voluntary." One scholar notes that "[t]he talismanic 'knowing and voluntary' phrase provides little by way of substantive analytic guidance, as the courts remarkably have not clearly articulated just how such essential characteristics are to be determined."119 Even the Ninth Circuit, which fully embraced the standard until it held that PMAAs were unenforceable per se, ${ }^{120}$ did not provide gnidelines to determine when a knowing and voluntary waiver of rights had occurred. ${ }^{121}$ Instead, its discussion of the standard "has been interpreted as requiring a fact specific analysis ... the primary factors being the language of the arbitration agreement, the employee's awareness of the agreement, and the einployee's understanding of what the agreement requires." ${ }^{122}$ Other courts

116. See supra Part I.C.I.a.

II7. See sources cited supra note 10.

I18. Compare Jean R. Sternlight, Rethinking the Constitutionality of the Supreme Court's Preference for Binding Arbitration: A Fresh Assessment of Jury Trial, Separation of Powers, and Due Process Concerns, 72 TuL. L. REv. 1, 58 (1997) (advocating a four-factor, fact-specific test for knowing and voluntary consent: (1) visibility and clarity of the agreement, (2) relative knowledge and economic power possessed by the parties, (3) the degree of voluntariness of the purported agreement, and (4) the substantive fairness of the purported agreement) with Reuben, supra note 10, at 1022 (advocating a three-factor test for knowing and voluntary consent: (1) visibility and clarity of the agreement on its face, (2) the general contractual environment in which the waiver was secured, and (3) the specific facts and circumstances of the actual bargaining over the waiver).

119. Reuben, supra note 10 , at 1020.

120. See Duffield v. Robertson, 144 F.3d 1182 (9th Cir. 1998), cert. denied, 525 U.S. 982 (1998).

121. Fitz, supra note 11 , at 75 .

122. Robert J. Lewton, Are Mandatory, Binding Arbitration Requirements a Viable Solution for Employers Seeking to Avoid Litigating Statutory Employment Discrimination Claims?, 59 ALB. L. Rev. 991, 1023 (1996). 
are equally unhelpful. ${ }^{123}$ One court requires that the agreement state the "significance of the right to a judicial forum," but does not define what this significance might be. ${ }^{124}$ Until courts define these terms, these cases will be of little help im fashioning a knowing and voluntary standard of consent in the pre-employment context.

\section{B. Misconceptions About the Law}

Most employees have little knowledge of their legal rights in employment. ${ }^{125}$ In a study by Professor Pauline Kim, employees were tested on their knowledge of unlawful versus lawful discharges. Less than ten percent of the employees answered more than half of the questions correctly. ${ }^{126}$ Employee ignorance also extends to knowledge about legal processes. Most employment applicants, though able to identify the most basic differenccs between arbitration and litigation, do not understand the remedial and procedural ramifications of consenting to arbitration. Very few are aware of what they are waiving when they agree to mandatory arbitration. ${ }^{127}$ Applicants assume they are afforded the same rights at arbitration as they are im jury trials, when in reality they often lose the ability to seek punitive damages and higher damage awards, more extensive discovery to bolster their claims, and other procedural rights that are guaranteed at trial. ${ }^{128}$ Most employecs only realize these significant differences after a dispute arises and the arbitration process begims. Unfortunately, by that time, it is too late since they have already waived their rights. Because

123. See supra note 77.

124. Trumbull v. Century Mktg. Corp., 12 F. Supp. 2 d 683 (N.D. Ohio 1998).

125. Melvin A. Eisenberg, The Limits of Cognition and the Limits of Contract, 47 STAN. L. Rev. 211, 241 (1995). See generally Pauline T. Kim, Norms, Learning, and Law: Exploring the Influences on Workers' Legal Knowledge, 1999 U. ILL. L. Rev. 447, 478 (1999) [heremafter Kim, Norms, Learning, and Law]; Pauline T. Kim, Bargaining with Imperfect Information: A Study of Worker Perceptions of Legal Protection in an At-Will World, 83 CoRNELl L. Rev. 105 (1997) [heremafter Kim, Bargaining with Imperfect Information]. Courts acknowledge this limitation as well. See, e.g., Runyan v. Nat'l Cash Register Corp., 787 F.2d 1039, 1044 (6th Cir. 1986) (upholding release where employee was well-paid, well-educated labor attorney and not a "layperson[ ] . . with little knowledge of their legal rights"). This lack of legal knowledge is by no means specific to employment. It pervades the housing, welfare, civil rights, consumer, and family law arenas as well. Kin, Norms, Learning, and Law, at 478 .

126. The questions were whether it was lawful for an employer to hire another person to do the same work at a lower rate of pay (lawful), to retaliate against an employee for reporting theft of company property by another employee to a supervisor (lawful), to fire an employee based on a mistaken belief that another employee stole money where the mistake can be proven (lawful), to retaliate against an employee for reporting violations of fire regulations to a government agency (unlawful), to fire an einployee based on personal dislike (lawful), and to retaliate against an employee for refusing to participate in an illegal billing practice (Imlawful). Kim, Norms, Learning, and Law, supra note 125, at 457; see also Fitz, supra note 11, at 79; Mandatory Arbitration of Statutory Employment Disputes, supra note 11, at 1684.

127. Rowe, supra note 11 , at 923,935 .

128. Stempel, supra note 49, at 300 n.217. 
applicants are usually ignorant of the significance of binding arbitration, PMAAs are likely to receive little deliberation at the time of signing. ${ }^{129}$

In addition to ignorance of procedural protections, einployees also tend to misunderstand the substantive protections they are entitled to by law. Professor Kim found that "workers ... systematically overestimate the protections afforded by law, believing that they have far greater rights against unjust or arbitrary discharges than they in fact have under an at-will contract." ${ }^{130}$ Employees generally believe they can only be fired for good or just cause. ${ }^{131}$ For example, a large percentage of the employees polled incorrectly believed that an employer could not fire them if they personally disliked them (89\%), wanted to hire someone for a lower wage (82\%), for reporting internal wrongdoing by another employee (79\%), and for mistakenly believing that another employee had committed wrongdoing (87\%). ${ }^{132}$ Erroneous notions about employment law are universal. These misconceptions are even held by college-educated and highly-compensated workers. ${ }^{133}$ Residents of states with varying degrees of legal protection for einployees-from California, where employees are afforded greater protection, to New York, where employees enjoy substantially less protectionall share an ignorance of the law. ${ }^{134}$

As though ignorance were not enough, these erroneous beliefs are often resistant to change. Even workers with past union affiliation, prior responsibility for hiring and firing, experience being fired, and lengthy work experience were likely to score poorly. ${ }^{135}$ Three-fourths of employees with a pre-existing belief that an einployer could only discharge them for just cause did not change their beliefs despite exposure to strong written

129. See Eisenberg, supra note 125, at 239 (noting that parties may give express conditions in contracts less deliberation because they are ignorant of the often harsh legal ramifications of breach).

130. Kim, Bargaining with Imperfect Information, supra note 125, at 106.

131. "[R]espondents consistently assumed that an employee cannot be discharged without a good reason, apparently believing that workers have something akin to just cause protection by law." Id. at 136.

132. Id. at 133-34.

133. The more educated and better paid an employee is, the more legal knowledge he or she generally has. Nonetheless, even these workers could not identify whether a discharge was lawful more than half the time. They are still "seriously misinformed." Id. at 144-45. See also Kim, Norms, Learning, and Law, supra note 125, at 476.

134. Kim, Bargaining with Imperfect Information, supra note 125, at 121 ("New York courts demand not only specific language [for an employer's promises to discharge only for cause], but proof of reliance as well. California courts, on the other hand, liberally enforce even general promises of job security."). See also Michael H. LeRoy \& Wallace Hendricks, Should "Agricultural Laborers" Continue to Be Excluded from the National Labor Relations Act?, 48 EMORY L.J. 489, 492 n.18 (1999) ("California's laws are favorable to workers."). Although the states surveyed-Missouri, California, and New York-all had at-will employment regimes, the error rate for California respondents was forty percent while the error rate for New York respondents was twenty-five percent.

135. Kim, Norms, Learning, and Law, supra note 125, at 451-52, 476. 
disclaimers describing an at-will employment relationship. ${ }^{136}$ Thus, it appears that erroneous beliefs about the law are unlikely to be corrected through informal learning processes. ${ }^{137}$

A likely reason for the prevalence of these misconceptions is that employees equate unfairness with unlawfulness. As Kim explains, "[W]orkers do not readily distinguish between informal norms and enforceable legal rights, between what they believe the law should be and what it actually is." 138 That is, because most workers believe that only discharges for just cause are fair, they believe that they are protected on the job from termination when in fact they can be fired for any reason, absent statutory protection. ${ }^{139}$ Employees do not realize that perceptions of unfairness and illegality often do not correlate.

Although Kim's norm theory explains why employees misunderstand their rights initially, it does not explain why employees do not eventually correct their mistakes through informal learning experiences. Kim posits that this resistance may be due in large part to daily associations and other experiences on the job that tend to reinforce the fairness norm or just cause standard. ${ }^{140}$ For example, many employers create a corporate culture that fosters teamwork and loyalty to the company. When an employee is discharged, the employer may tell remaining employees that it had good reason for firing the employee. Indeed, many employers give the appearance of fairness by using fairness language in personnel manuals or handbooks even though the reality is far from fair. ${ }^{141}$ Still other employers may promulgate an at-will policy but utilize a just cause standard. That is, they may have at-will employment policies in employee manuals, handbooks and agreements, but im practice, only discharge employees for good cause. Alternatively, the misunderstanding may not be due to the einployer's behavior at all. Perhaps employees already believe that just cause provisions are the norm, so they tend only to see evidence that confirms this belief while iguoring contradictory evidence. ${ }^{142}$ Regardless of the reasons for their faulty beliefs, employees ultimately undervalue job security provisions in their employment contracts because of their mistaken notions of legal protection.

136. Nearly three-fourths of the respondents who thought that a cost-saving discharge was unlawful continued to believe that the discharge was unlawful given a clear disclaimer in a personnel manual stating that the "[c]ompany reserves the right to discharge employees at any time, for any reason, with or without cause." Id. at 457, 509.

137. Id. at 451-52, 473 .

138. Id. at 448 .

139. Id. at 480 .

140. Id. at 494-95.

141. Id. at 494, 496; Clyde W. Summers, The Contract of Employment and Rights of Individual Employees: Fair Representation and Employment at Will, 52 FORDHAM L. REv. 1082, 1105-06 (1984) [hereinafter Sunmers, Contract of Employment].

142. Kim, Norms, Learning, and Law, supra note 125, at 496. 


\section{Cognitive Biases ${ }^{143}$}

Barriers to knowing and voluntary consent go beyond misconceptions about the law. Even assuming that people have the correct information, human cognition studies show that they often process that information incorrectly, leading to severe errors, biases, and inconsistencies in judgment. ${ }^{144}$ Cognitive limitations on the ability of people to accurately asscss situations may limit the likelihood that people will act in their own best interests. Legal scholars have applied cognitive theories to various areas of law, ${ }^{145}$ including jury behavior, judicial decision making, and litigation strategies. Few, however, have applied it to contract law $^{146}$ and to PMAAs in particular. ${ }^{147}$ The following sections consider optimistic bias, poor risk perception, representative heuristics, and faulty schemas in the preemployment context and demonstrate how these cognitive biases can create huge obstacles to establishing a knowing and voluntary standard of consent.

\section{Optimistic Bias and Poor Risk Perception}

People tend to be overwhelmingly optimistic about their lives. This phenomenon applies across a broad range of situations from accident avoidance, ${ }^{148}$ to home hazards, ${ }^{149}$ to drinking problems. ${ }^{150}$ It also infiltrates daily life, relationships, and personal and professional success. ${ }^{151}$ Both

143. For a particularly well-written book on this subject matter, see SCOTT PLous, THE Psychology of Judgment and Decision Making (1993), winner of the William James Book Award.

144. Id. at 107-08.

145. See Christine Jolls et al., A Behavioral Approach to Law and Economics, 50 STAN. L. Rev. 211 (1995) (behavior of lawyers and judges); Howard Latin, "Good" Warnings, Bad Products, and Cognitive Limitations, 41 UCLA L. Rev. 1193 (1994) (consumer product wamings); Jeffrey J. Rachlinski, Gains, Losses, and the Psychology of Litigation, 70 S. CAL. L. Rev. 113 (1996) (litigation strategies); Gary T. Schwartz, Reality in the Economic Analysis of Tort Law: Does Tort Law Really Deter?, 42 UCLA L. Rev. 377 (1994) (tort law and deterrence). See generally Cass R. Sunstein, Behavioral Analysis of Law, 64 U. CHI. L. REv. 1175 (1997).

146. Melvin A. Eisenberg argues that a recognition and understanding of the psychological constraints on decision making should play a central role in the development of contract law. See Eisenberg, supra note 125, at 211.

147. But see Cole, supra note 8.

148. See Colin F. Camerer \& Howard Kunreuther, Decision Processes for Low Probability Events: Policy Implications, 8 J. PoL'y ANAL. \& MGMT. 565, 569 (1989); W. KIP VISCUSI \& WeSLEY A. Magat, Learning About RISK: Consumer and Worker Responses to Hazard InFormation 95 (1987).

149. See VIscusi \& MAGAT, supra note 148, at 94-95.

150. See Neil D. Weinstein, Unrealistic Optimism About Future Life Events, 39 J. Personality \& Soc. PsYchOL. 806, 809-14 (1980).

151. For example, when American couples about to get married were questioned about their futures together, they correctly noted that fifty percent of couples divorce, but believed that their own chances of divorce were zero. Lynn A. Baker \& Robert E. Emery, When Every Relationship is Above Average: Perceptions and Expectations of Divorce at the Time of Marriage, 17 L. \& HuM. BEHAV. 439,443 (1993). Similarly, female respondents estimated that forty percent of divorced spouses pay court-awarded alimony, yet all of them believed that if divorced, their spouse would pay alimony 
sexes fall prey to optimistic bias ${ }^{152}$ as do both laypersons and experts. ${ }^{153}$ Intelligence also plays no role in reducing over-optimism. ${ }^{154}$ To complicate matters, the bias persists even when people are confronted with valid negative data. ${ }^{155}$

One particularly pernicious aspect of being overly optimistic is that people systematically underestimate risk. ${ }^{156}$ Low-probability risks, in particular, are underestimated and oftentimes ignored. For example, in a study about homeowner insurance in flood-prone areas, nearly a third of uninsured homeowners thought they would suffer no damage in a severe flood and over a quarter of them thought their damage would be $\$ 10,000$ or less. ${ }^{157}$ They had little idea of the real probability of a future disaster and the cost of damage. Even those who were more informed of expected losses and premium costs declined to buy insurance. People tended to buy insurance for high-probability, low-loss hazards and decline insurance for low-probability, high-loss hazards. ${ }^{158}$ Another way people evaluate risk is by assessing the desirability or undesirability of events. Speciflcally, people overestimate desirable events and underestimate undesirable ones. ${ }^{159}$ In other words, positive events seem more likely than negative ones. ${ }^{160}$

Applicants at the contracting stage of employment are not immune from optimistic bias. Few applicants think prospectively about potential conflict before they are employed and few consider the possibility or probability of the relationship going sour, ${ }^{161}$ let alone a situation arising that would necessitate taking a dispute to court. Even if applicants did consider this possibility, they would probably dismiss it. As one scholar notes, "[T] he employee is unlikely to properly value the [mandatory arbitration]

without a court order. Id. In another study, six times as many college students believed they were more likely to enjoy their postgraduate job compared to their average same-sex classmate than those who did not. Weinstein, supra note 150 , at 809-14.

152. Baker \& Emery, supra note 151, at 443.

153. Paul Slovic et al., Facts Versus Fears: Understanding Perceived Risk, in JUDGment Under Uncertainty: Heuristics and Biases 463, 475-78 (Daniel Kahneman, Paul Slovic \& Amos Tversky eds., 1982) [hereinafter JUDGMENT UNDER UNCERTAINTY].

154. Plous, supra note 143, at 219.

155. Jonathan St. B. Evans, Bias in Human Reasoning: Causes and Consequences 121 (1989); Craig A. Anderson \& James J. Lindsay, The Development, Perseverance, and Change of Naïve Theories, Soc. Cognition, 16(1), at 19 (1998).

156. Eisenberg, supra note 125 , at 225 ("If people are unrealistically optimistic, they will systematically underestimate risks. If people systematically underestimate risks, they will be unrealistically optimistic.”).

157. Howard Kunreuther \& Paul Slovic, Economics, Psychology, and Protective Behavior, AM. ECoN. Rev., May 1978 (papers \& proceedings), at 64, 66-67.

158. Id. at 67 . There is also evidence that people overestimate low-probability risks when confronted with them. Eisenberg, supra note 125, at 223-25. See also infra Part 1V.C.

159. PLous, supra note 143 , at 143.

160. Id.

161. See Eisenberg, supra note 125, at 227 (stating that it is difficult to imagime all the ways a contract may be breached at some later date). 
clause because he will tend to discount the probability that he will ever engage in a dispute with his employer. After all, he has never had a dispute with an employer in the past and he knows that, in general, such disputes happen to other people."162 Therefore, even if applicants were informed that fifty percent of employees who sign PMAAs will have an employment dispute that will result in final, binding arbitration, few would believe that they would become one of those employees. ${ }^{163}$ Optimistic bias, therefore, significantly impedes an applicant's careful deliberation of a PMAA. ${ }^{164}$

\section{Representative Heuristics and Faulty Schemas}

In human decision making, people rarely make decisions based on all relevant information. Instead, they use shortcuts called heuristics that enable them to more easily process massive amounts of information. ${ }^{165} \mathrm{Al}$ though heuristics often lead to optimal decisions, they can also lead to systemic cognitive biases in judgments, particularly when situations are unknown, uncertain, or unpredictable. ${ }^{166}$ This section discusses the representative heuristic, the faulty schemas that can result from the use of heuristics, and how this process can negatively affect an employee's consideration of a PMAA.

The representative heuristic concerns the extent to which people search for information when making decisions. Instead of considering all relevant information, they take a portion of data and judge it to be representative of the entire data set. ${ }^{167}$ For instance, people systematically and erroneously use small samples of present events to predict future ones. ${ }^{168}$ Such predictions can often be accurate. On the other hand, they can also be

162. Cole, supra note 8, at 481. Professor Eisenberg makes a similar argument with respect to liquidated damage provisions. He argues that parties rarely give any consideration to liquidated damage provisions because they expect to perform and do not expect the clause to ever be used against them. Thus, the cost of careful deliberation does not seem worthwhile to them-"[C]ontracting parties are likely often to not even try to think liquidated damages provisions through, and are therefore unlikely to fully understand the implications of such provisions." Eisenberg, supra note 125, at 227.

163. Baker \& Emery, supra note 151 , at 443 . The "it won't happen to me" mentality is illustrated in an interview with a New York subway graffitist who was badly burned in an electrical fire. He admitted that just two weeks ago he had read about a boy who was crushed to death while painting graffiti on trains. The graffitist stated, "I remember laughing about it thinking that he must be some kind of dude who didn't know what he was doing." Richard E. Nisbett et al., Popular Induction: Information Is Not Necessarily Informative, in JUDGMENT UNDER UNCERTAINTY, supra note 153 , at 101,116 .

164. See Cole, supra note 8, at 481; Eisenberg, supra note 125, at 227.

165. Russell B. Korobkin \& Thomas S. Ulen, Law and Behavioral Science: Removing the Rationality Assumption from Law and Economics, 88 CALIF. L. REv. 1051, 1076 (2000).

166. Sarah Lichtenstein et al., Calibration of Probabilities: The State of the Art to 1980, in JUDGMENT UNDER UNCERTAINTY, supra note 153, at 306, 333. See also Slovic et al., supra note 153, at 464-65; Korobkin \& Ulen, supra note 165, at 1083-84.

167. Eisenberg, supra note 125, at 222; Tversky \& Kahneman, Judgment Under Uncertainty: Heuristics and Bias, in JUDGMENT UNDER UNCERTAINTY, supra note 153, at 3, 4.

168. Eisenberg, supra note 125, at 222. 
remarkably inaccurate. Nevertheless, individuals tend to heavily rely on this shortcut to facilitate cognitive processing. The employment context is particularly rife with this heuristic.

The representative heuristic emerges in the employment context when applicants use a small sample of positive or neutral interactions they have had with their new employer as reliable benchmarks of the relationship in the future. Professor Eisenberg, recognizing that potentially long-lasting and personal relationships, like employment, are subject to the representative heuristic, notes, "[P]arties are likely to ... erroneously take the state of their relationship at [the time the contract is made] as representative of the relationship's future; and to give too little thought to and put too little weight on the risk that the relationship will go bad."169 This cognitive limitation is reinforced by the employer's appearance of fair employment practices or use of employment materials with "fairness" language, which only tends to confirm their representative views that the remainder of the employment relationship will be fair and favorable. In reality though, employment relationships tend to be even more ambiguous, unreliable, and unstable than objects or non-social events. ${ }^{170}$

Moreover, many of these cognitive limitations are not only based on a limited amount of information, but inaccurate information grounded in stereotypes or preconceived ideas. For example, if people are told that a certain individual is very shy, withdrawn, meek, tidy, orderly, but has little interest im people, they are likely to think that this person is a librarian, rather than another professional since the aforementioned characteristics are representative of the librarian stereotype. ${ }^{171}$ Just like people associate certam behavioral qualities with certain occupations, they may also associate certain legal structures or processes, like arbitration, with certain legal mandates, like just cause protection. ${ }^{172}$ To further understand why such cognitive associations occur, it is important to understand how the human mind organizes information.

When a person receives information, the first step in giving that information meaning is to fit it into some preexisting knowledge structure, or schema. ${ }^{173}$ This is known as "priming" or activating the schema with which

169. Id. at 252. Professor Eisenberg specifically argues that the representative heuristic applies to liquidated damage provisions. Id. at 228.

170. Shelley E. Taylor, The Availability Bias in Social Perception and Interaction, in JudGmenT UNDER UNCERTAINTY, supra note 153, at 190, 191.

171. PLous, supra note 143, at 4.

172. See Ellen Waldman, Substituting Needs for Rights in Mediation: Therapeutic or Disabling?, 5 PSYCHOL. PUB. POL'Y \& L. 1103, 1118-20 (1999) (arguing that a participant's expectations in alternative dispute resolution may incorporate whatever flawed perceptions they have of their legal rights).

173. Thomas K. Srull \& Robert S. Wyer, Jr., Category Accessibility and Social Perception: Some Implications for the Study of Person Memory and Interpersonal Judgments, 38 J. PERSONALITY \& Soc. PsYchol. 841, 842 (1980) (encoding human behavior). 
it is associated. ${ }^{174}$ Which schema is instantiated by a particular piece of incoming information is largely a function of the perceiver's prior experience, either actual or vicarious. ${ }^{175}$ Once primed, the schema influences perceptions by similarly categorizing information that is directly related to or associated with it. ${ }^{176}$ For example, in one study, subjects were exposed to the words "elm," "oak," and "maple." name as quickly as possible the color of ink in which certain words were written and to ignore the word itself. When subjects were shown the word "tree," they had a harder time naming the ink color and ignoring the word. This is because the word "tree" activated a schema of the associated words "elm," "oak," and "maple."

Similarly, when applicants think of arbitration, they are likely to trigger schemas related to benefits like just cause protection. ${ }^{178}$ Arbitration is closely associated with unions and civil service protection, which almost always require that employers discharge or discipline employees for good cause. ${ }^{179}$ Therefore, just cause protection may appear to be a natural component of arbitration proceedings and, as a result, the "arbitration" schema is likely to be considered positive since employees associate it with a benefit. Unfortunately, this schematic association creates errors in judgment ${ }^{180}$ since arbitration rarely ever means just cause protection outside the union context. ${ }^{181}$

An employee's lack of experience with arbitration is likely to reinforce this positivism. The average employee has never taken a claim to arbitration or seen many headline grabbers reciting horrid stories of arbitration. ${ }^{182}$ Recent polls support this theory. Employees polled about

174. Id.

175. See Jum C. Nunnally, Individual Differences in Word Usage, in DiREctions iN Psycholinguistics 203 (Sheldon Rosenberg ed., 1965).

176. See Strull \& Wyer, supra note 173, at 847 ("[O]nce the behavior is encoded in terms of the primed category and the target is assigned the corresponding trait, the effects of priming may generalize to judgments along dimensions that are not directly implied by the target's behavior but are thought to be associated with the originally primed trait ....").

177. See Higgins et al., Category Accessibility and Impression Formation, 13 J. ExPERIMENTAL Soc. PsYchol. 141, 143 (1977).

178. See id. (exposure to certain trait terms may aetivate the trait category and related categories).

179. Kim, Bargaining with Imperfect Information, supra note 125, at 107; Clyde W. Summers, Individual Protection Against Unjust Dismissal: Time for a Statute, 62 VA. L. Rev. 481, 497 (1976) [hereinafter Summers, Time for a Statute] (noting that public employees covered by civil service laws or regulations generally have protection against unjust dismissal). The emergence of arbitration as a popular mechanism for resolving disputes is, in fact, borrowed from the collective bargaining arena, where unions insisted on just cause protection for workers in their agreements. See Summers, Contract of Employment, supra note 141, at 1085-86.

180. Higgins et al., supra note 177 , at 142 (commenting that categorization can introduce bias and distortion in the initial imterpretation, encoding, and retrieval of information).

181. See infra notes 263-64.

182. One might think that publicity surrounding bitter employment disputes may cause applicants to reassess the risks of litigation. This has not been the case though because publicity tends to be 
arbitration overwhelmingly believe that arbitration is more favorable than litigation and that their chances of success are better in arbitration. ${ }^{183}$ While these ideas may be based on independent considerations, they may also be another disguise for their mistaken notions of just cause protection and faulty arbitration schemas. ${ }^{184}$

The arbitration schema is likely to be positive even for employees that have had bad experiences with arbitration, such as union members. Because union members are protected by just cause provisions in their collective bargaining contracts, ${ }^{185}$ a union meinber's arbitration schema is likely to be synonymous with just cause protection. Professor Kim assumed that union employees were more likely to know the true nature of their legal rights, ${ }^{186}$ but it may be that applicants with prior union membership may be less likely to know their rights because of faulty schemas leading them to believe that just cause protection is the norm in the workplace. Faulty schemas, therefore, perpetuate misunderstandings of the law.

Finally, the interplay of other factors solidify these faulty schemas in the minds of applicants. Employers give the appearance of fairness by using fairness language in personnel manuals or handbooks. ${ }^{187}$ Employers may knowingly or unknowingly state or imply that PMAAs are a benefit of einployment or, in the alternative, downplay their significance. And even if employers tell applicants about the mandatory arbitration clause, few are likely to hear "mandatory," let alone grasp the significance of this term.

On the other hand, the notion that arbitration brings greater legal protection may not be a result of the employer's actions at all. Employees may associate arbitration with increased legal protection because they have the tendency to seek information that confirms, rather than disconfirms, what they already believe to be true. In one study, for example, a significant number of einployees wrongly believed that informal employer statements implying greater job protections than those found in an offer letter or personnel manual created legal protections against unlawful discharge. ${ }^{188}$ These informal statements confirmed their pre-existing assumptions of just

concentrated on the dispute itself rather than the use of arbitration to resolve the dispute. Cole, supra note 8 , at 481 .

183. See Maltby, supra note 27, at 53-54. See generally infra Part II.C.1.

184. In a survey by Princeton Survey Research Associates, eighty-three percent of employees thought arbitration was "good" or "very good." Sixty-two percent thought that arbitrators would resolve disputes more fairly than courts, seventy-one percent thought it would be easier for an employee to get a fair hearing, and seventy-three percent thought that they would be better off in arbitration than litigation. Interestingly though, seventy-eight percent of employees rejected mandatory arbitration and believed that arbitration should be the choice of both parties. Maltby, supra note 27, at 53-54.

185. See supra note 179 and accompanying text.

186. Kim, Norms, Learning, and Law, supra note 125, at 494, 496.

187. Id.; Sunmers, Contract of Employment, supra note 141, at 1105-06.

188. Kim, Bargaining with Imperfect Information, supra note 125, at 138. 
cause protection. The tendency to associate arbitration with legal protection rather than the loss of legal rights is consistent with this behavior.

\section{$* * *$}

The cognitive biases discussed above disincentive applicants from carefully considering the implications of a PMAA. They suggest that applicants heavily discount the possibility of an employment dispute at the contracting stage of employment. Faulty judgments and mental processing reinforce applicants' false perceptions of just cause protection, thereby further distilling hopes that applicants will understand or even know the rights they are waiving. However, this may be assuming too much since another barrier, the involuntary nature of the agreement, suggests that applicants may not consider the terms of a PMAA at all.

\section{Coercive Condition of Employment}

The greatest barrier to achieving knowing and voluntary consent to pre-dispute mandatory arbitration is the simple fact that it is a condition of employment. During a subcommittee hearing on the FAA, one senator explained his concern about binding arbitration agreements:

The trouble ... is that a great many of these contracts that are entered into are really not voluntary things at all ... . A man says, "These are our terms. All right, take it or leave it." Well there is nothing for the man to do except to sign it; and then he surrenders his right to have his case tried by the court, and has to have it tried before a tribunal in which he has no confidence at all. ${ }^{189}$

In other words, applicants can never truly voluntarily consent to a PMAA if they have no choice but to sign it if they want the job.

One might argue that the choice to sign a PMAA, even if it is adhesive, is still a choice because applicants can apply for another job. However, "such Lochner-era logic grossly distorts the reality of the bargaining environment. The selection of an alternative method of dispute resolution is supposed to represent a choice between trial and another means of resolving conflicts, not a choice between working in a given industry and finding another livelihood." ${ }^{190}$ Such an argnment also fails to recognize that most people view their jobs as their most valuable possession. ${ }^{191}$ More fundamentally, it assumes worker mobility and a healthy job market.

The assumption that workers can decline PMAA-based employment is unlikely to be true. In a recent California decision on mandatory arbitration, the court noted that

189. Circuit City v. Adams, 532 U.S. 105, 139 n.3 (2001) (Souter, J., dissenting) (citing Hearing on S. 4213 and S. 4214 before a Subcommittee of the Senate Committee on the Judiciary, 67th Cong., 4th Sess., 9 (1923) (statement of Senator Walsh)); Gilmer v. Interstate/Johnson Lane Corp., 500 U.S. 20,39 (1991) (Stevens, J., dissenting) (same).

190. Reuben, supra note 10, at 1026.

191. Summers, Time for a Statute, supra note 179, at 532. 
in the case of pre-einployment arbitration contracts, the econoinic pressure exerted by employers on all but the most sought-after employees may be particularly acute, for the arbitration agreement stands between the employee and necessary employment, and few employees are in a position to refuse a job because of an arbitration requirement. ${ }^{192}$

Efforts to find another job are curtailed by limited information and resources. ${ }^{193}$ Moreover, PMAAs have now become standard boilerplate provisions $\mathrm{m}$ most employment agreenents. ${ }^{194}$ Therefore, there is little opportunity to shop around.

The nature of the agreement further makes knowing and voluntary consent unlikely. PMAAs are not bargained for contracts; there is no opportunity to negotiate. And without negotiation, deliberation is unlikely. Conditioning employment on the waiver of judicial rights discourages applicants from exercising even minimal effort to read or understand the PMAA. A potential einployee is unlikely to devote resources to try to understand something that he or she cannot change or escape. Thus, the waiver, as a prerequisite of employment, chills any meaningful mquiry that an applicant might make into the arbitration agreement. ${ }^{195}$

On the other hand, in negotiated contracts, parties have an incentive to incur the costs of seeking information and deliberating because they have a vested interest in gaining favorable terms. They evaluate their wants, needs, and desires. Professor Melvin Eisenberg describes the process as follows:

Parties are normally the best judges of their own utility, and normally reveal their determinations of utility in their promises. Bargain promises are normally made in a deliberative manner for personal gain .... [T] hese propositions ... rest on the empirical preinise that in making a bargain a contracting party will act with full cognition to rationally maximize his subjective expected utility. ${ }^{196}$

If applicants could bargain at the contracting stage of employment, they would deliberate the terms of a PMAA. This deliberation would help alleviate the barriers to achieving knowing and voluntary consent discussed above because applicants would have greater incentives to gain knowledge in order to make proposals with the most utility. In the process of deliberating, an applicant would have the chance to challenge faulty assumptions

192. Armendariz v. Found. Health Psychcare Servs., Inc., 6 P.3d 669, 690 (Cal. 2000).

193. 'Most actors either don't want to expend the resources required for comprehensive search and processing or recognize that comprehensive search and processing would not be achievable at any realistic cost." Eisenberg, supra note I25, at 214.

194. See supra notes I6-17 and accompanymg text.

I95. See Eisenberg, supra note 125, at 242-43.

196. Id. at $21 \mathrm{I}-12$. 
about legal protections and stereotypical notions of arbitration. In addition, negotiation would help combat cognitive biases because employees would be more likely to consider the risks of certain proposals and concessions and would therefore be less optimistic. Employers might also check their self-interests due to the give-and-take nature of bargaining. ${ }^{197}$

The ability of employers to require PMAAs as a mandatory condition of employment is a result of their superior bargaining power. ${ }^{198}$ One federal district court judge noted, "[W]aivers of individual rights may reflect not efficient decision-making, but inefficient '[e]conomic rents' providing windfalls to the parties in superior bargaining positions." 199 Employers are repeat players in the employment marketplace, regularly hiring workers and drafting employment agreements. Although the expense of legal information is high, employers are willing to invest in the information because they know that in the long run the economies of scale will tip in their favor, and the beneflts will exceed the costs. ${ }^{200}$ As a result, employers are significantly more educated in legal matters than employees. ${ }^{201}$

In contrast, employees are one-shot players. Employees change jobs and sign agreements far less often than employers hire employees. As such, employees have generally had only a few opportunities to negotiate agreements with employers. Furthermore, they have had fewer experiences with litigation, if any at all. In sum, employees lack the organization and sophistication of employers. In fact, "[t] he one-shot player's limited exposure to contracts and the legal system are the deflning aspects of his nature."202 Therefore, it is both reasonable and rational that employees do not seek costly legal information or hire counsel in order to decide whether to sign a PMAA. ${ }^{203}$

The employer's superior access to legal information creates significant advantages in drafting employment agreements. Employers hire attorneys to draft agreements like PMAAs that are in the employers' best interests. Although employers could create agreements that are mutually beneficial to the employer and employee, they rarely do so. ${ }^{204}$ Further,

197. Cole, supra note 8, at 472-73.

198. EEOC Policy Statement, supra note 7.

199. Martens v. Smith Barney, Inc., 181 F.R.D. 243, 253 (S.D.N.Y. 1998) (citing Susan RoseAckerman, Inalienability and the Theory of Property Rights, 85 Colum. L. Rev. 931, 940-41 (1985)).

200. Cole, supra note 8, at 452.

201. See id. at 453 ("[T] he repeat player may have a much better understanding of the risks and benefits of various dispute resolution mechanisms.").

202. Id. at 452 .

203. Randy E. Barnett, The Sound of Silence: Default Rules and Contractual Consent, 78 VA. L. REv. 821, 886-94 (1992) [hereinafter Barnett, The Sound of Silence] (arguing that it is rational for oneshot players to remain rationally ignorant and not seek legal counsel to learn default rules).

204. Summers, Contract of Employment, supra note 141, at 1108 (stating that employers will have contracts drawn by lawyers and limit employees to contract rights as meager and illusory as possible); H.R. REP. No. 101-664, at 54 (1990) ("[W]aivers [of the right to trial] are initiated by einployers, not 
since employers and employees are not equal players in the employment market, employees have no real bargaming power vis-à-vis their employers. ${ }^{205}$ Employers have no incentive to check their self-interests, and einployees have no power to make thein do so. ${ }^{206}$ The employer's self-interest and bargaining advantage are reflected in contract terms favorable to the employer. ${ }^{207}$

Despite the repeat player problem, the Supreme Court has refused to recognize unequal bargaining power as a sufficient basis to imvalidate PMAAs. The Court in Gilmer clearly stated, "Mere inequality in bargaining power... is not a sufficient reason to hold that arbitration agreements are never enforceable in the employment context."208 Nevertheless, the Court has used unequal bargaining power as a basis to invalidate waivers in other contexts such as waivers of minimum wage requirements at the contracting stage of employment. ${ }^{209}$ Congress has also been sensitive to the issue of unequal bargaining power in the context of wage negotiation. ${ }^{210}$

employees. Any benefit that flows from the use of a waiver flows entirely and directly to the employer.").

205. Summers, Contract of Employment, supra note 141, at 1109 ("When employees have no collective agreement to protect them, but must bargain individually, they are often at the mercy of the employer.").

206. Cole argues that employers in negotiation with other repeat players have an economic incentive to check self-serving behavior. The employer's interest at the contracting stage is to maintain a good commercial reputation and a sinooth working relationship. The employer knows that if he drafts an unfair or oppressive clause, this may result in the loss of a business opportunity and the loss of repeat or referral business. On the other hand, an einployer does not have the econounic incentive to check self-serving behavior with an employee because employees are not equal partners, do not have the ability to negotiate, and can inore easily be replaced. Cole, supra note 8, at 472-73.

207. See, e.g., Armendariz v. Found. Health Psychcare Servs., Inc., 6 P.3d 669 (Cal. 2000) (employee required to arbitrate claims and limited in danages while employer free to choose between arbitral or judicial forums and not subject to damage limitation); Kinney v. United Healthcare Servs., Inc., 70 Cal. App. 4th 1322 (1999) (employee unilaterally compelled to subnit to arbitration); Stirlen v. Supercuts, Inc., 51 Cal. App. 4th 1519 (1997) (mandatory arbitration agreennent exempted from arbitration certain employer claims, limited remedies, waived employees' objections to jurisdiction and service, and provided for termination of employee's eniployinent and salary pending resolution of employer's clainis); Saika v. Gold, 49 Cal. App. 4th 1074 (1996) (arbitration clause provided for trial de novo if arbitrator's award against the enployer was $\$ 25,000$ or greater).

208. Gilmer v. Interstate/Johnson Lane Corp., 500 U.S. 20, 33 (1991). But see Manuszak, supra note 9, at 397-98 (arguing that the Suprene Court's decision in Mastrobuono v. Shearson Lehman Hutton, Inc., 514 U.S. 52 (1995) (striking down choice-of-law provision that would have prevented enployee from receiving a punitive damage award) demonstrates that the Court may now be inore concemed with the balance of power between employees and employers in the PMAA context).

209. Tony \& Susan Alamo Foumd. v. See'y of Labor, 471 U.S. 290, 302 (1985) (holding that employees cannot waive minimum wage requirements of the FLSA even when such waivers are knowing and voluntary and enphasizing that the superior bargaining power of einployers must not be allowed to "coerce employees ... or to waive their protections under the Act").

210. "Congress recognized the significant inequalities in bargaining power that exist between employers and employees, and accordingly made the FLSA's provisions inandatory. Thus, it has long been settled that FLSA rights inay not be abridged by private contract or otherwise waived by private agreenient ...." S. REP. No. 101-79, at 4 (1989). 
A similar rationale could apply to PMAAs. At the very least, a heightened standard of consent can be applied to these agreements. But as the preceding sections demonstrate, implementing a knowing and voluntary consent standard to PMAAs is problematic given these ambiguous terms as well as human shortcomings in legal knowledge and judgment. The specific consent regime under the OWBPA solves at least the first problemdefining "knowing and voluntary."

\section{III \\ KNOWING and Voluntary CONSENT UNDER the Older Workers Benefit Protection ACT}

The OWBPA is the only anti-discrimination statute that legislatively requires that waivers be knowing and voluntary. Scholars have widely supported applying the OWBPA's consent standard to PMAAs, ${ }^{211}$ but neither Congress nor the courts have done so. ${ }^{212}$ The considerations that drove Congress to create the OWBPA standard for ADEA waivers are particularly noteworthy.

\section{A. The OWBPA}

By the 1990s, it became common practice for employers to offer employees severance or early retirement packages as an inducement to retire. ${ }^{213}$ As a condition to receiving these packages, employees were required to execute waivers of present, future, actual, and possible claims of age discrimination. Concerns arose over the voluntariness of these

211. See supra note 11 .

212. See Gilmer, 500 U.S. at 29 (stating in dicta that the OWBPA does not preclude binding arbitration); Rosenberg v. Merrill Lynch, Pierce, Fenner \& Smith, lnc., 170 F.3d 1 (1st Cir. 1999) (holding that Congress did not intend to preclude pre-dispute arbitration agreeinents when it enacted the OWBPA); Seus v. John Nuveen \& Co., 146 F.3d 175, $181-82$ (3d Cir. 1998), cert. denied, 525 U.S. 1139 (1999) (stating in dicta that Congress did not intend for the OWBPA requirements to apply to nonprocedural rights such as the right to a judicial forun); Williams v. Cigna Fin. Advisors, Inc., 56 F.3d 656, 660-61 (5th Cir. 1995) (refusing to apply OWBPA requirements to PMAAs absent clear congressional intent); Rice v. Brown Bros. Harriman \& Co., No. 96-ClV-6326(MBM), 1997 WL 129396, at *5 (S.D.N.Y. Mar. 21, 1997) (same holding as Seus dicta); Kahalnik v. John Hancock Funds, Inc., No. 95-C3933, 1996 WL 145842, at *3 (N.D. III. Mar. 27, 1996) (stating that the OWBPA only bars the waiver of substantive claims, not the waiver of the right to a judicial forum). But see Duffield v. Robertson Stephens \& Co., 144 F.3d 1182, 1190 n.5 (9th Cir. 1998) (stating in dicta that all rights under the ADEA, including the right to a jury trial, inust be knowing and voluntary and referencing the OWBPA); Torrez v. Pub. Serv. Co. of N.M., 908 F.2d 687, 690 (10th Cir. 1990) (extending OWBPA requirements under the ADEA to releases under Title V11). See also Amy R. Blair, Note, Mandatory Arbitration Agreements of ADEA Claims: An Analysis of Their Validity Under the Older Workers Benefit Protection Act, 16 OHı ST. J. oN DisP. REs. 195 (2000) (arguing that Congress intended the OWBPA standards to prohibit waivers of judicial remedies unless such waivers are knowing and voluntary). More courts have applied a more general knowing and voluntary consent standard to PMAAs. See cases cited supra notes 74 and 77.

213. Howard C. Eglit, Age Discrimination, $\$ 4.10$ ( $2 \mathrm{~d}$ ed. 2000 ). 
plans. ${ }^{214}$ Voluntary retirement plans often meant that if an employee did not accept the retirement package they would be laid off. ${ }^{215}$ Congress was concerned about the "unfair and abusive waiver practices"216 that often defined these arrangements, including the "manipulation of older workers," 217 the workers" "lack of information or expertise," 218 and the "coercion of older workers."219 Congress's "major concern"220 though was mass reduction plans (i.e. group termination and reduction programs) because " $t]$ he preemptive waiver of rights occurs before a dispute has arisen and indeed before an employee is even aware of any potential or actual pattern of discrimination." ${ }^{221}$ Waivers effectively chilled any meaningful inquiry into whether employees were victims of unlawful age discrimination. ${ }^{222}$

In 1990 , Congress responded by anending the $\mathrm{ADEA},{ }^{223}$ which prohibits arbitrary age discrimination of older workers in the workplace. The amendment became known as the OWBPA, ${ }^{224}$ which statutorily requires stringent adherence to consent standards to ensure that waivers obtained in individual ${ }^{225}$ and group termination contexts are truly knowing and voluntary. The stated purpose of the amendment is "to ensure that older workers are not coerced or manipulated into waiving their rights to seek legal relief

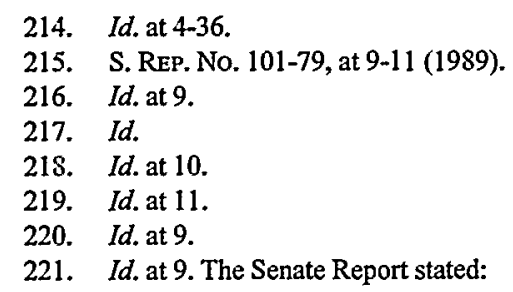

The trademark of involuntary termination programs is a standardized formula or package of employee benefits that is available to more than one employee. The trademark of voluntary reduction programs is a standardized formula or package of benefits that is designed to induce employees voluntarily to sever their einployment. In both cases, the terms of the programs are not subject to negotiation between the parties. In addition, employees affected by these programs have little or no basis to suspect that action is being taken based on their individual characteristics. Indeed, the enployer generally advises them that the termination is not a function of their individual status. Under these circunstances, the need for adequate information and access to advice before waivers are signed is especially acute.

S. REP. No. 101-263 (1990), reprinted in 1990 U.S.C.C.A.N. 1509, 1538. In contrast, Congress believed that in the context of individual agreements, employees knew of the actual or expected action and could negotiate with the employer to resolve any differences. Id. at 1537.

222. S. Rep. No. 101-79, at 12 (1989).

223. 29 U.S.C. $\$ 621-634$ (2001).

224. Pub. L. No. 101-433, 104 Stat. 978 (1990). The name of the amendment contained in the official Senate report, S. REP. No. 101-79, is the Age Discrimination in Employment Waiver Protection Act of 1989 (S. 54). The amendment was superseded by S. 1511, which was passed on September 24, 1990. However, the OWBPA imcorporates by reference the legislative history of the Waiver Protection Act contained in S. REP. No. 101-79.

225. In these agreements, an individual waives rights to clains for actual or expected adverse action. In other words, a bona fide claim already exists or potentially exists. This differs from the group termination and exit incentive plans where employees have little or no basis to suspect discrimination. See supra note 221. 
under the ADEA."226 The OWBPA prohibits waivers of claims before they arise. Congress felt it a "basic principle of fairness that employees should not be permitted to waive rights or claims on a prospective basis."227

\section{B. OWBPA's Knowing and Voluntary Consent Model}

The OWBPA sets up a presumption that a waiver is not knowing and voluntary unless certain requirements are met. ${ }^{228}$ Meeting these requirements is only a threshold matter; a court may still find that the waiver is otherwise unenforceable. ${ }^{229}$ The requirements are as follows:

(A) the waiver must be part of an agreement between the individual and the employer that is written im a manner calculated to be understood by such an individual, or by the average individual eligible to participate;

(B) the waiver must specifically refer to rights or claims arising under this Act;

(C) the individual must not waive rights or claims that may arise after the date the waiver is executed;

(D) the individual must waive rights or claims only in exchange for consideration in addition to anything of value to which the individual is already entitled;

(E) the individual must be advised in writing to consult with an attorney prior to executing the agreement;

(F) the individual must be given a period of at least 21 days within which to consider the agreement;

(G) the agreement must provide that for a period of at least 7 days following the execution of such agreement, the individual may revoke the agreement, and the agreement shall not become effective or enforceable until the revocation period has expired. ${ }^{230}$

Congress explicitly stated that these requirements were to be strictly adhered to in order to protect individuals covered under the Act, ${ }^{231}$ and

226. S. REP. No. 101-79, at 2 (1989).

227. S. REP. No. 101-263 (1990), reprinted in 1990 U.S.C.C.A.N. 1509, 1538.

228. The burden of these requirements is on the party urging validity of the waiver, which is usually the defendant. 29 U.S.C. $\S 626(f)(3)$ (2002).

229. 29 U.S.C. $\$ 626(f)(1)(2002)$ ("[A] waiver may not be considered knowing and voluntary unless at a minimum [the waiver fulfills certain requirements.]"). See also EGLIT, supra note 213, $\S 5.65$.

230. 29 U.S.C. $\S 626(f)(1)(A)-(G)(2002)$. Specific requirements for exit incentive or einployment termination programs have been oinitted.

231. The emphasis on strict adherence is largely a result of the fact that the validity of unsupervised waivers was a substantial departure from requirements under the FLSA, after which the ADEA was modeled. S. REP. No. 101-263 (1990), reprinted in 1990 U.S.C.C.A.N. 1509, 1537. See Oubre v. Entergy Operations, Inc., 522 U.S. 422 (1998) (holding that an ADEA waiver that does not comply with the threshold requirements of the OWBPA is void and cannot be used to bar suit by an employee or former employee). Waivers that are part of an exit incentive or group termination program have even more stringent requirements. See 29 U.S.C. $\$ 626(\mathrm{f})(1)(\mathrm{F})(\mathrm{ii})$ and $(\mathrm{H})(2002)$ (requiring a 
courts have faithfully honored this intent..$^{232}$ Congress has approved $\mathrm{d}^{233}$ and courts have consistently applied a totality of the circumstances standard in determining whether these requirements have been met. These relevant factors include (1) the clarity and specificity of the waiver language; (2) the einployee's education and business experience; (3) amount of time the einployee had for deliberation before signing the agreeinent; (4) whether the einployee knew or should have known his rights upon execution of the release; (5) whether the employer encouraged the employee to seek counsel; (6) whether the employee did in fact receive the benefit of legal counsel where there was an opportunity to negotiate the terms of the agreement; and (7) whether consideration was given in exchange for a waiver and if accepted, whether the agreement confers on the einployee benefits that the employee was not already entitled to by law. ${ }^{234}$

\section{Applying the OWBPA's Consent Model to PMAAs}

\section{Contributions}

At the outset, it is important to note that the OWBPA's consent model highlights the same concerns about employee manipulation and unequal bargaining power that are present at the contracting stage of employment. ${ }^{235}$ In passing the OWBPA, Congress expressed disapproval with how employees were presented with standardized packages of einployee benefits as an inducement to retire: "Older workers are in an unequal bargaining position when faced with a situation that leaves them very few alternatives. They are often coerced or manipulated into signing waivers as a condition of their participation in exit incentive or early retirement programs."236 Senator Melcher further elaborated:

[The waiver requirements are] important because of the inherently different bargaining power of einployers and employees. There will always be employees who feel that if they do not sign a waiver they will not only be out of a job, but also will forfeit any present or future benefits to which they may otherwise be entitled. On top of this, surveys have shown that most older workers don't know

\footnotetext{
45-day period in which employees can consider the waiver and mandated disclosures in order for employees to assess whether or not they have been the victim of discrimination).

232. Oubre, 522 U.S. at 427 (noting that OWBPA requirements are strict and that the Court is "bound to take Congress at its word"); Savoie v. Terrebonne Parish Sch. Bd., CIV.A.98-1006-T, 2000 WL 136008 (E.D. La. 2000) (holding that even though the spirit of the agreement suggests a knowing and voluntary waiver, it does not technically conform with the OWBPA requirements and therefore cannot be upheld); Butcher v. Gerber Prods. Co., 8 F. Supp. 2d 307, 314 (S.D.N.Y. 1998) ("Since the OWBPA establishes mimmum or threshold requirements, absolute technical compliance with its provisions is required.").
}

233. S. REP. No. 101-263 (1990), reprinted in 1990 U.S.C.C.A.N. 1509, 1537.

234. Cirillo v. Armco Chem. Co., 862 F.2d 448, 451 (3d Cir. 1988).

235. Belton, supra note 11, at 962 .

236. H.R. REP. No. 101-664, at 30 (1990). 
their rights under the ADEA. Nobody can waive his or her rights if he or she is unaware of what they involve..$^{237}$

Members of Congress voiced concern that these retircment packages were being presented on a "take-it-or-leave-it basis" without negotiation. ${ }^{238}$ Congress found this unfair and inconsistent with the intent of the ADEA. ${ }^{239}$

Ironically, although all of the above can be said about PMAAs, Congress has not implemented such a standard in the pre-employment context. ${ }^{240}$ Nevertheless, some of the OWBPA's knowing and voluntary rcquirements are directly transferable to the contracting stage of employment. In particular, the OWBPA requires that agreements be written in a manner that can be understood by the average participant and that they specifically refer to the rights and claims arising under the Act. Congress recognized that participants do not always know the law at issue. These requirements can be easily applied to PMAAs at the contracting stage of employment. Applying these requirements to PMAAs would help define the elusive meaning of "knowing and voluntary."241 It would discourage employers from writing agreements in legalese and would help ensure that applicants are well-informed and understand the rights they are waiving. They should be staple prerequisites of any knowing and voluntary consent standard.

\section{Shortcomings}

Many features of the OWBPA consent model, on the other hand, do not translate well to the pre-employment context. For example, employers are statutorily required under the Act to advise individuals in writing to seek the advice of an attorney. ${ }^{242}$ The court considers whether the employer encouraged the employee to seek counsel and whether the cmployee did in fact have the benefit of counsel. ${ }^{243}$ The advice of counsel can be a greatly effective measure to ensure knowing and voluntary consent. ${ }^{244}$ Attorneys can educate applicants and correct misconceptions about the nature and extent of their legal rights. ${ }^{245}$ They can help the employee assess the risks

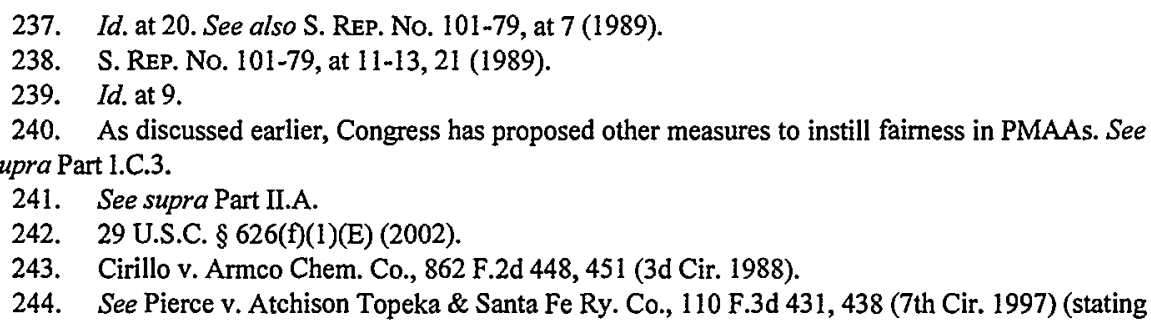
that a knowing and voluntary waiver is presumed if an attorney participated in negotiating an ADEA release).

245. See id.; Valenti v. Int'l Mill Servs., Inc., 610 F. Supp. 36, 38 (E.D. Pa. 1985) (comparing the competence of an experienced labor lawyer with the naiveté of an engineer plaintiff who probably "never thought at the time he was being discharged that he may have been discriminated against because of his age or that he possibly had an age discrimination claim"). Cf. Runyan v. Nat'l Cash 
of signing the waiver and the value of job security provisions like just cause protection. Through their knowledge and experience, attorneys can mitigate the employee's predisposition to be overly optimistic about the future employment relationship. ${ }^{246}$ After all, the employment lawyer's profession is defined in large part by employment relationships gone sour. Thus, the advice of an attorney can do much to ensure the existence of knowing and voluntary consent.

Although the advice of counsel would benefit job applicants, few would independently seek legal advice before signing a PMAA, nor could they be expected to. First, legal advice is time consuming and expensive. Unlike employers, most prospective employees do not have ready access to attorneys. Second, at the contracting stage, usually nothing negative has happened in the einployment relationship. Third, as discussed above, applicants tend to believe that nothing bad will happen on the job in the future. Applicants generally think they are immune from workplace hazards. They are overly optimistic and underestimate the likelihood of an employment dispute. As a result, job applicants are unlikely to spend time and money seeking legal advice regarding an agreement they believe will never be invoked in the first place. ${ }^{247}$

The advice of an attorney requirement makes more sense in the OWBPA context because employees at the post-employment stage have already invested in the employment relationship. Most do not want to leave their jobs; they are being induced or forced to leave. Older workers, im particular, find themselves in very vulnerable positions. When the OWBPA was passed, age discrimination victims typically earned $\$ 15,000$ a year, had less than a fifty percent chance of finding new employment once laid off, and had little or no savings. ${ }^{248}$ The average job applicant generally earns more money than an age discrimination victim or older worker, and has more mobility and greater job opportunities. Older workers have more

Register Corp., 787 F.2d 1039, 1044 (6th Cir. 1986) (upholding release as knowing and voluntary where plaintiff was a well-paid, well-educated and experienced labor attorney). See also Waldman, supra note 172, at 1119 ("Attorneys frequently unust dampen disputant needs that, like a funhouse mirror, depict a grossly overblown or hideously ennaciated picture of the actual rights being reflected.").

246. In passing the OWBPA, a House committee report recognized the benefits of legal counsel:

Given the complexity of issues involved and the inherently unequal bargaining position of the parties, the Committee expects the employer to encourage einployees to consult with counsel to determine what legal rights they may have.... [I]t is virtually inportant that the einployee understand the inagnitude of what he or she is undertaking. Legal counsel is in the best position to help the individual reach that understanding.

H.R. REP. No. 101-664, at 49 (1989).

247. Barnett, The Sound of Silence, supra note 203, at 886 ("With small one-shot transactions it inay be irrational for either party to pay a lawyer to provide information concerning the default rules. Put another way, in light of the stakes involved, it may be rational for the parties to remain ignorant of the background rules.").

248. S. REP. No. 101-79, at 9 (1989). 
at stake, and therefore are more likely to seek the advice of counsel in making what they recognize to be a significant decision. The substantive nature of the waiver at retirement also demands more consideration than does a waiver in a PMAA. OWBPA waivers involve the forbearance of legal claims altogether, rather than a change in forum. With a PMAA, an employee still has a forum for her legal dispute as she can appear before an arbitrator rather than a judge or jury. ${ }^{249}$

Above all else, applicants are unlikely to seek the advice of counsel because they are required to sign a PMAA as a condition of employment. No matter how much time or money they invest in understanding the mandatory arbitration clause or agreement, they still must sign it in order to get the job. As emphasized earlier, few applicants will forego a job opportunity for a clause they believe will never come into play. ${ }^{250}$ The only benefit they can gain from legal advice is a more knowledgeable understanding of the arbitration process and the rights they are surrendering. Advice cannot and will not change the lack of choice.

Another important distinction between the two contexts arises in an examination of the conferred benefits. The OWBPA allows participants to waive their rights, but only in exchange for consideration that is in addition to anything of value to which they are already entitled. ${ }^{251}$ This conferred benefit is usually in the form of financial incentives. ${ }^{252}$ To strengthen this requirement, the OWBPA totality of circumstances standard requires time for deliberation and an opportunity to negotiate. ${ }^{253}$ In the OWBPA setting, employees have opportunities to change the terms under which they retire and to enhance their status. They can demand a larger severance package, bargain for more time, and make other requests that mcrease the attractiveness of the waiver. Further, the value the employee provided during the years of employment service creates bargaining leverage, as does the implied threat that they can file a discrimination claim under the ADEA.

These features are notably absent from the pre-employment context. PMAAs are conditions of employment and applicants are required to waive

249. An argument can be made that the waiver of procedural rights is a substantive waiver given the distinct differences between litigation and arbitration. According to the Supreme Court in Alexander v. Gardner-Denver Co., 415 U.S. 36 (1974), the arbitration forum "affects the scope of the substantive right to be vindicated." 415 U.S. at 56 . Gardner-Denver, however, has been heavily disfavored by the Court in recent years. See Gilmer v. Interstate/Johnson Lane Corp., 500 U.S. 20, 33-35 (1991).

250. See Armendariz v. Found. Health Psychcare Servs., lnc., 6 P.3d 669, 690 (Cal. 2000).

251. 29 U.S.C. $\$ 626(f)(1)(D)$ (2002).

252. SEN. REP. No. 101-263 (1990), reprinted in 1990 U.S.C.C.A.N. 1509, 1532; EgLIT, supra note 213 , at $\$ 4.10 \&$ n. 152 .

253. See supra note 234 and accompanying text. 
their rights without any quid pro quo benefit. ${ }^{254}$ Negotiation is nonexistent where standardized employment agreements have become the norm. Even if job applicants could negotiate additional benefits prior to employment, employers would wait to hire the applicant with the least burdensome demands. This would only encourage applicants to ask for very little, if anything at all. Applicants are of little value to an employer who has not invested resources in the applicant and can always hire someone else. In sum, applicants will not spend time or money considering a PMAA when they know at the outset that they have no power or leverage to have the agreement withdrawn.

For the same reasons, job applicants are unlikely to take advantage of the consideration and revocation periods that the OWBPA requires. Time will not assist an applicant who does not believe that he has anythimg important to consider. Therefore, blanket recommendations that applicants seek the advice of counsel and take time to consider PMAAs are empty suggestions with little chance of success. More must be done than a simple extension of the OWBPA consent model to PMAAs.

\section{IV}

\section{The Meaningful Choice and Informed Consent Regime}

As the previous Part demonstrates, although the OWBPA requirements make worthwhile contributions to creating a knowing and voluntary standard of consent, these requirements alone would not be effective at the contracting stage of employment. The key lies in creating incentives for applicants to take advantage of the OWBPA's requirements. This can be accomplished through a new proposal entitled the Meaningful Choice and Informed Consent Regime ("the Proposed Regime"), which modifies and expands the OWBPA's knowimg and voluntary standard of consent. The Proposed Regime eliminates the mandatory condition of PMAAs and replaces it with a meaningful choice between gaining just cause protection or having the unlimited right to litigate employment disputes in a judicial forum. Moreover, it accounts for the barriers to achieving knowing and voluntary consent and remedies the shortcomings of the OWBPA consent model. The following section presents the Proposed Regime and explains why it is a superior model $\mathrm{m}$ the pre-employment context than the OWBPA's knowing and voluntary consent model.

\section{A. Instilling Meaningful Choice}

The OWBPA model's key feature is voluntary choice. "The purpose of the OWBPA is to assure that the worker has the leisure and the facts 
necessary to enable him to make a sensible choice, which implies that he has a choice rather than simply is being terminated."255 The OWBPA consent model also requires that the employee receive an additional benefit in exchange for waiving claims or rights. ${ }^{256}$ The first part of the Proposed Regime, meaningful choice, would establish a comparable scheme in the PMAA context.

The Proposed Regime eliminates the inandatory condition of einployment and presents applicants with two choices: (1) sign a PMAA and receive just cause protection from dismissal and other disciplinary actions in exchange for the waiver of judicial forum rights, ${ }^{257}$ or (2) not sign the PMAA, remain an at-will employee, but receive the unlinited right to take employment claims to a judicial forum. These choices are "meaningful" because applicants have something to gain regardless of which option they choose. ${ }^{258}$ They are also "meaningful" because they cure existing disincentives to thoroughly review and consider these agreemcnts. ${ }^{259}$ Through choice, applicants will want to maximize their benefits and will therefore have an incentive to seek knowledge in order to evaluate thcir options.

The first choice gives applicants the opportunity to gain just cause protection on the job. Just cause protection requires that disciplinary actions be taken against an employee only for good or just cause. ${ }^{260}$ It replaces the at-will default rule that an employee can be discharged or disciplined for good reason, bad reason, or no reason at all. ${ }^{261}$ People in many trades and professions, particularly non-union, private sector employees,

255. Blackwell v. Cole Taylor Bank, 152 F.3d 666, 669 (7th Cir. 1998).

256. 29 U.S.C. $\$ 626(f)(1)(D)$ (2002).

257. Under existing law, some courts enforce PMAAs by finding the employer's consideration of the jobseeker's application, the employment offer, or its promise to arbitrate adequate consideration for a valid contract. See Michalski v. Circuit City Stores, Inc, 177 F.3d 634, 636-37 (7th Cir. 1999) (employer's promise to be bound by agreement sufficient); Johnson v. Circuit City Stores, Inc., 148 F.3d 373, 378 (4th Cir. I998) (employer's promise to be bound by agreement sufficient); Gibson v. Neighborhood Health Clinics, Inc., I21 F.3d 1126, 1131-32 (7th Cir. 1997) (employer's promise to be bound, promise to hire, or promise of continued employment is sufficient); O'Neil v. Hilton Head Hosp., 115 F.3d 272, 275 (4th Cir. 1997) (mutual promise to arbitrate is sufficient consideration). But this line of reasoning misses the mark-but for the PMAA, the employer would hire the applicant after the offer of employment is made. Only the PMAA stands in the way of gainful employment. See Phillips v. CIGNA Invs., Inc., 27 F. Supp. 2d 345 (D. Conn. 1998) (mere continuation of employment not sufficient).

258. In Montana, Puerto Rico, and the Virgin Islands, just cause protection is state law. Kim, Bargaining with Imperfect Information, supra note 125 , at 107 n.9. Therefore, applicants in these states would not find the choice between just eause protection and unlimited right to a judicial forum meaningful. Instead, applicants in these states should be provided with the proposed federal disclosures outlined in Part IV.B. and be given the choice of signing a PMAA.

259. See Barnett, The Sound of Silence, supra note 203, at 853-55.

260. Sunmers, Time for a Statute, supra note 179, at 482-83. For substantive and procedural principles on just cause protection in arbitration, see $i d$. at 501-08.

261. In just a few states and territories (Montana, Puerto Rico, and the Virgin Islands), just cause protection is the law. See supra note 258. Other states have attempted just cause legislation but have been unsuccessful. See Summers, Contract of Employment, supra note 141, at 1109 nn.105-06. 
are employed at-will, ${ }^{262}$ while nearly all union employees are covered by just cause provisions in their collective bargaining agreements. ${ }^{263}$ Just cause protection for non-union private employees is very rare. ${ }^{264}$

Offering just cause protection as the conferred benefit is appropriate in the pre-employment context for a number of reasons. To begin with, most applicants already believe that they have just cause protection on the job. Therefore, employment contracts are being formed where one party is mistaken about the terms of the agreement. However, Phillip Barnett notes that this should not result in a binding contract. Barnett's theory argues that true consent in contracts should reflect what the parties would have asked for had they speciflcally addressed the issue. ${ }^{265}$ Barnett argues that when one party is likely to be misinformed on the law, the default rule should reflect the expectations of the misinformed. In particular, he argues that boilerplate provisions should ordinarily reflect commonplace expectations or understandings of the community to which the misinformed party belongs. ${ }^{266}$ At the contracting stage of employment then, it inakes sense to have a just cause benefit since inost applicants believe they have just cause protection anyway. ${ }^{267}$

262. Richard A. Epstein, In Defense of the Contract at Will, 51 U. CHI. L. REv. 947, 951 (1984). The employment-at-will doctrine is limited, however, by discrimmation statutes and certain exceptions, such as violations of public policy. Id.

263. Kin, Bargaining with Imperfect Information, supra note 125, at 107. In 2001, only 14.8 percent of employed wage and salary workers in the United States were represented by unions. For a summary of union affiliation of employed wage and salary workers by selected characteristics, see Bureau of LABor Statistics, UnION MEMBERSHIP (ANNUAL), at tbl. 1 (2001) ("union affiliation of employed wage and salary workers by selected characteristics"), available at http://www.bls.gov/ news.release/union2.t01.htm.

264. In one study examining five states (Califormia, Michigan, New York, Texas, and Virginia), only about fifteen percent of the employers surveyed offered just cause protection to their non-union employees. J. Hoult Verkerke, An Empirical Perspective on Indefinite Term Employment Contracts: Resolving the Just Cause Debate, 1995 WIs. L. Rev. 837, 867 (1995).

265. See Barnett, The Sound of Silence, supra note 203, at 885-94. See also William V. Gould IV, The Idea of the Job as Property in Contemporary America: The Legal and Collective Bargaining Framework, 1986 BYU L. REv. 885, 911 (arguing that the law should reflect existing social norms by instilling a presumption in favor of just cause discharge); Arthur S. Leonard, A New Common Law of Employment Termination, 66 N.C. L. REv. 631, 680-83 (1988) (same); Summers, Contract of Employment, supra note 141, at 1105 (same). But cf. Riehard H. McAdams, The Origin, Development, and Regulation of Norms, $96 \mathrm{MrCH}$. L. REv. 338, 412 (1997) (arguing that esteem competition may produce norms that are unnecessary or excessive); Eric A. Posner, Law, Economics and Inefficient Norms, 144 U. PA. L. REv. 1697, 1711-25 (1996) (arguing that norms are likely to be inefficient due to information lags, collective action problens, and envy); Edward B. Rock \& Michael L. Wachter, The Enforceability of Norms and the Employment Relationship, 144 U. PA. L. REv. 1913, 1932-38 (1996) (arguing that the norm of just cause discharge may be efficient but would reduce the overall efficiency of the employment relationship). See generally Kim, Norms, Learning, and Law, supra note 125, at 498-506 (discussing these various theories).

266. Barnett, The Sound of Silence, supra note 203, at 890-91; Summers, Contract of Employment, stupra note 141 , at 1103.

267. Just cause protection is also overwhelmingly supported by the public. See generally Elletta Sangrey Callahan, Employment at Will: The Relationship Between Societal Expectations and the Law, 
Next, there is a lack of feasible alternative benefits to offer applicants at the contracting stage of employment. Awarding applicants higher salaries or better benefit packages for signing PMAAs would be too intrusive on an employer's managerial discretion. It would also create unwarranted disparities in pay between like individuals based solely on whether they signed a PMAA. In practice, such a scheme would only encourage applicants to sign the agreement in order to gain greater benefits and further discourage applicants from carefully deliberating the agreement's terms. Greater pay and benefits would be a much more attractive option for applicants than having the unlimited right to a judicial forum because applicants do not value remedial provisions at the outset of an employment relationship $^{268}$ and mistakenly believe they already have just cause protection. Finally, just cause protection can remedy some of the limitations of mandatory arbitration. Although a full discussion of this issue is beyond the scope of this Comment, ${ }^{269}$ there are a couple of points worth highlighting:

\section{Just Cause Claims Are More Appropriate for Arbitration than Discrimination Claims}

After the Gilmer decision in 1991, employers rushed to fashion employment agreements requiring binding arbitration for all employment disputes. ${ }^{270}$ These disputes included wrongful discharge cases and discrimination claims under Title VII and the ADEA. ${ }^{271}$ Although the breadth of arbitration cases has expanded with a nod of approval from the courts, ${ }^{272}$ many believe that discrimination claims are not well-suited for arbitration. ${ }^{273}$ The Supreme Court, before it embraced arbitration, emphasized the "special role of the arbitrator, whose task is to effectuate the intent of the parties rather than the requirements of enacted legislation" and

28 Am. Bus. L.J. 455 (1990); Frank S. Forbes \& Ida M. Jones, A Comparative, Attitudinal, and Analytical Study of Dismissal of At-Will Employees Without Cause, 37 LAB. L.J. 157 (1986).

268. "Provisions on remedies are of secondary importance to [employees] compared to the substantive content of the contract." ARTHUR L. CORBIN, CORBIN ON CONTRACTs, $\S 24.27 C(B)$ (revised ed. 200I).

269. For articles on the limitations of mandatory arbitration, see text and discussion supra note 27.

270. Howard, supra note 11, at 255.

27I. Id. at 255-56.

272. See, e.g., Gilmer v. Interstate/Johnson Lane Corp., 500 U.S. 20, 20 (199I).

273. Geraldine Szott Moohr, Arbitration and the Goals of Employment Discrimination Law, 56 WASH. \& LEE REv. 395, 420-39 (1999) (arguing that mandatory arbitration agreements should not be enforced because the strong public policy in eradicating discrimination in the workplace dictates a public forum to handle these disputes); Donna Meredith Matthews, Note, Employment Law After Gilmer: Compulsory Arbitration of Statutory Antidiscrimination Rights, I8 BERKELEY J. EMP. \& LAB. L. 347, 351-52 (1997). See also Stephen J. Ware, Default Rules from Mandatory Rules: Privatizing Law Through Arbitration, 83 MNN. L. REV. 703, 7I9-25 (1999) [heremafter Ware, Default Rules] (arguing that arbitration privatizes and thus jeopardizes public law). 
the "specialized competence of arbitrators [that] pertains primarily to the law of the shop, not the law of the land."274

This view is fair since arbitrators are not always well-versed in employment law, ${ }^{275}$ may decide cases without the benefit of evidence, ${ }^{276}$ and are not required to consistently or accurately apply discrimination law. ${ }^{277}$ Arbitrators sometimes willfully ignore the law because they think it is the right thing to $\mathrm{do}^{278}$ and are sometimes guided only by their personal sense of fairness. ${ }^{279}$ Not only do arbitrators misapply discrimination law, but review is extremely difficult ${ }^{280}$ and reversibility for legal error is rare. Arbitrators must either have "manifest disregard for the law," or the award must violate public policy. ${ }^{281}$ Rarely will courts find that an arbitrator has deliberately disregarded the law. ${ }^{282}$ In fact, courts often enforce arbitral decisions even when they know that the arbitrator inisapplied the law. ${ }^{283}$ But it is probably more often the case that courts do not closely monitor arbitration awards, so most cases of arbitral failure to apply the law probably go undetected by courts. ${ }^{284}$

Furthermore, there is validity to the argument that discrimination claims, which go to the heart of our civil rights, merit the careful attention of a jury of one's peers rather than an arbitrator. ${ }^{285}$ The Proposed Regime would place Title VII claims back in the hands of federal courts and alleviate the concern that arbitrators decide "public law concepts," while leaving

274. Alexander v. Gardner-Denver Co., 415 U.S. 36, 57-58 (1974).

275. Mandatory Arbitration of Statutory Employment Disputes, supra note 11, at 1680. See generally Ware, Default Rules, supra note 273, at 719-25. Even though sixteen percent of arbitrators have never read a judicial opinion involving Title VII and forty percent do not read labor advance sheets to keep abreast of developinents in Title VII, half of the arbitrators in each of these former groups nonetheless felt professionally competent to decide legal issues involving employinent discrimimation. Michael A. Landrum \& Dean A. Trongard, Judicial Morphallaxis: Mandatory Arbitration and Statutory Rights, 24 WM. MitCHELL L. REv. 345, 391 (1998).

276. Kandel, supra note 27, at 1001 .

277. See generally Ware, Default Rules, supra note 273.

278. In one survey, eighty percent of the arbitrators felt that they should reach decisions by applying substantive rules of law, but ninety percent also thought that they could ignore the law if they thought they could make a more just decision without it. Soia Mentschikoff, Commercial Arbitration, 61 CoLuM. L. REv. 846, 861 (1961).

279. Kandel, supra note 27, at 1001.

280. Arbitrators rarely record their proceedings or write opimions. One judge remarked, "For all we know, the arbitrators concluded that the sun rises in the west, the earth is flat, and damages have nothing to do with the intentions of the parties or the foreseeability of the consequences of a breach." Perini Corp. v. Great Bay Hotel \& Casmo, Inc., 610 A.2d 364, 392 (N.J. 1992) (Wilentz, C.J., concurring).

281. Ware, Default Rules, supra note 273 , at 724.

282. Id. ("If the arbitrator makes an egregious error out of ignorance, rather than deflance- 'pure heart, empty head'-there is no manifest disregard of law.").

283. See, e.g., Moncharsh v. Heily \& Blase, 832 P.2d 899, 919 (Cal. 1992) ("[T] he existence of an error of law apparent on the face of the award that causes substantial injustice does not provide grounds for judicial review."). See also Ware, Default Rules, supra note 273, at 724 n.82.

284. Ware, Default Rules, supra note 273, at 723.

285. See Moohr, supra note 273. 
just cause claims in the hands of arbitrators. ${ }^{286}$ Just cause cases, unlike discrimination claims, are the forte of arbitration. Arbitrators are accustomed to dealing with these cases, and there is a large body of just cause precedent. ${ }^{287}$ All factors considered, arbitrators are better equipped to decide just cause claims than employment discrimination claims, making the former more appropriate for arbitration than the latter.

\section{Just Cause Protection Levels the Playing Field}

As repeat players, employers can track an arbitrator's record. ${ }^{288}$ They can shop for an arbitrator who will be most favorable to their case. ${ }^{289}$ In fact, some employers are now trying to impose confidentiality provisions in PMAAs, positioning themselves in a "vastly superior legal posture since as a party to every arbitration it will know every result and be able to guide itself and take positions accordingly, while [employees] will have to operate in isolation and largely in the dark." ${ }^{290}$ Also, the employer usually pays the arbitrator and the two often have repeated informal relations. ${ }^{291}$ Arbitrators may be consciously or unconsciously biased in favor of the employer. ${ }^{292}$ Some have claimed that arbitrators are particularly biased in discrimination cases because arbitrators tend to be white males over the age of sixty. ${ }^{293}$

In other words, the scales are weighed heavily against the employee before he or she even gets to arbitration. Just cause protection helps to restore this imbalance by requiring the employer to affirmatively show the existence of just cause ${ }^{294}$ rather than requiring the employee to prove actual

286. Alexander v. Gardner-Denver Co., 415 U.S. 36, 57 (1974).

287. Summers, Time for a Statute, supra note 179, at 500 ("On the bare words 'just cause' arbitrators have built a comprehensive and relatively stable body of both substantive and procedural law."). Arbitrators are not bound by other arbitration decisions but are usually aware of the pattern of decisions of other arbitrators and are reluctant to deviate far from that pattern. Id. at 501.

288. EEOC Policy Statement, supra note 7.

289. See Engalla v. Permanente Med. Group, Inc., 983 P.2d 903 (Cal. 1997) (noting that employer kept extensive records about arbitrators it hired and delayed scheduling of arbitration, creating inference that employer did so in order to seek a favorable arbitrator).

290. Ting v. AT \& T, 182 F. Supp. 2d 902, 932 (N.D. Cal. 2002).

291. Cole, supra note 8 , at 477.

292. Id. at 478 ("Economic coercion clearly plays some role in a system where an arbitrator who regularly finds in favor of complaining employees may expect that the employer will be reluctant to rehire him in the future."); Michael Pye et al., The Right to Refuse Unsafe Work in New Zealand, N.Z. J. IND. REL. 199216 (June 1, 2001), available at 2001 WL 22252902 (citing U.S. study finding that in the majority of cases reviewed, arbitrators demonstrated a deference and bias towards the prerogative of management to manage).

293. See generally Cherry, supra note 6; Kandel, supra note 27, at 963-64 (securities industry); Ellen Forman, Arbitration A Rights Firestorm; Weary of Long Cases, Firms Want System That Worries Workers, Sun-SEnTinel, June 7, 1998, at Sunday Business Section (citing 1994 GAO study finding arbitration panels to be 89 percent male and 97 percent white).

294. Summers, Time for a Statute, supra note 179, at 504. 
discrimination, a very difficult hurdle to overcome. ${ }^{295}$ Therefore, applicants are likely to have more success in arbitration with a just cause standard. ${ }^{296}$ However, this conclusion should not obscure the fact that employers still fare better at arbitration, regardless of the standard. ${ }^{297}$ The more often an employer arbitrates, the more successful that employer is at arbitration. ${ }^{298}$ For these reasons, just cause protection is a sensible and appropriate benefit for applicants to receive in exchange for waiving their rights to a judicial forum.

\section{B. Educating Through Informed Consent}

In order to appreciate the Proposed Regime's meaningful choices, the Regime also requires that applicants be informed about their legal rights and the arbitral process. Applicants cannot appreciate the significance of the choices unless they understand the at-will nature of their present circumstances. This can be achieved through the second element of the Proposed Regime-informed consent. The goal of the Regime's informed consent component is two-fold: (1) to structure PMAAs in a manner that facilitates understanding, and (2) to provide measures that will educate applicants about their legal rights and gnide them in making meaningful choices.

lnformed consent begins with the agreement itself. Pre-dispute mandatory arbitration clauses should be contained in a separate agreement. Too often, applicants are directed to sign an employment agreement containing a waiver clause in fine print without any material discussing the waiver or

295. A plaintiff under Title VII must prove that he or she (1) was a member of a protected group; (2) was qualified for the position; (3) was discharged or suffered some other adverse employment action; and that (4) the position remamed open and the employer subsequently filled the position with someone outside of the plaintiff's protected class. Reeves v. Sanderson Plumbing Prods., Inc., 530 U.S. $133,142(2000)$. Then the burden shifts to the employer to show that the plaintiff was discharged or otherwise adversely treated for a legitimate, nondiscriminatory reason. Once the employer satisfies this burden, the burden shifts back to the plaintiff to show that the legitimate reason(s) offered by the employer are not true reasons, but are pretexts for discrimination. The ultimate burden of proving that the employer intentionally discrimimated agaimst the plaintiff remains at all times with the plaintiff. Id. at 143-43; McDonnell Douglas Corp. v. Green, 411 U.S. 792, 802-04 (1973).

296. An American Arbitration Association study shows that in more than half of discharge cases brought before arbitrators, the employee is reinstated with or without full backpay. Summers, Time for a Statute, supra note 179 , at 507.

297. One survey estimates that at least seventy percent of arbitration decisions are made in favor of the employer. See Stuart H. Bompey \& Andrea H. Stempel, Four Years Later: A Look at Compulsory Arbitration of Employment Discrimination Claims After Gilmer v. Interstate/Johnson Lane Corp., 21 Employee Rel. L.J. 21, 43 (1995); Liz Halloran, Companies Develop Their Own Brand of Justice: Forced Arbitration Keeps Grievances Out of Court, HARTFORD Courant, March 8, 1999, at Main (A). But cf. Maltby, supra note 27, at 45-46 (reporting different studies finding that employee win rates at arbitration are sixty-four percent, sixty-three percent, and fifty-one percent).

298. EEOC Policy Statement, supra note 7. 
mandatory arbitration. ${ }^{299}$ PMAAs are usually included in a packet of application materials or an employee handbook that applicants must acknowledge receiving. When the PMAA or clause is hidden in a handbook or manual, it has little chance of being read. Therefore, requiring a separate agreement increases the odds that the applicant will read it.

Similar to the OWBPA's requirement for ADEA waivers, PMAAs must also be clear and specific. PMAAs tend to be written $\dot{m}$ ambiguous or obscure language incomprehensible to the average worker. ${ }^{300}$ Therefore, employers should be required to draft PMAAs in simple and understandable language so that applicants can understand the siguificance of the agreement regardless of their education or business experience. ${ }^{301}$ This generally requires the "elimination of technical jargon and of long, complex sentences." ${ }^{902}$ In addition, PMAAs must clearly specify the rights and kinds of claims that are subject to mandatory arbitration. ${ }^{303}$

The crux of the informed consent component of the Proposed Regime, however, is its written and verbal federally-mandated disclosures, which present the two meaningful choices, educate applicants about their legal rights, and provide important information about the differences between arbitration and litigation. There is no such comparable scheme in the OWBPA. However, there is a similar scheme now required by the NASD in the securities industry, which provides some guidance for the substance of such disclosures. ${ }^{304}$ Disclosure statements are necessary to correct false

299. See, e.g., Rosenberg v. Merrill Lynch, Pierce, Fenner \& Smith, lnc., 170 F.3d 1 (1st Cir. 1999); Hossam M. Fahmy, Arbitration: Wiping Out Consumer Rights?, 64 TEx. B.J. 917,918 (2001) ("Companies and corporations tend to add mandatory arbitration clauses im fine print of contracts, often in ways that are nearly invisible to all but the most careful readers.").

300. See Cole, supra note 8 , at 475.

301. See S. REP. No. 101-79, at 20 (1989).

302. 29 C.F.R. $\S 1625.22$ (b)(3) (1998). In 1998, the Equal Employment Opportunity Commission promulgated a regulation interpreting and applying the OWBPA waiver provisions. It is codified at 29 C.F.R. $\$ 1625.22$ (1998).

303. Prudential Ins. Co. of Am. v. Lai, 42 F.3d 1299, 1305 (9th Cir. 1994). A House report supporting the OWBPA stated, "This degree of clarity and specificity increases the chances that individuals will know their rights upon execution of a waiver." H.R. REP. No. 101-664, at 48 (1990).

304. The NASD disclosures are modelled on disclosures given to customers when signing PMAAs with member firms and are contained in Rule 3110(f) of the industry's Uniform Arbitration Code. Constantine N. Katsoris, The Resolution of Securities Disputes, 6 FORDHAM J. CoRP. \& Fin. L. 307, 320 (2001). The NASD disclosures inform registrants that the form contains a PMAA and specifies where it is located. It then directs registrants to read the clause. The disclosures paraphrase the arbitration clause and state that by signing the clause, they give up their right to sue in court, including a jury trial. The disclosures also clarify that arbitration awards are generally final and binding, and that modification or reversibility of the award are rare. Furthermore, the disclosures provide that discovery is limited, arbitrators do not have to explain the reasons for their awards, arbitrators may be public or industry arbitrators, and there inay be time linits for bringing a claim. Disclosures are required each time an employee signs a $U-4$ form. Employees who use private arbitration agreeinents rather than the U-4 Form are expected to abide by the disclosure rule or risk facing an adverse decision im litigation. Self-Regulatory Orgs., Exchange Act Release, No. 34-41461, 1999 SEC LEXIS 1099 (May 27, 1999) (setting forth proposed rule); Self-Regulatory Orgs., Exchange Act Release, No. 34-42061, 1999 SEC 
legal misconceptions and to create uniformity in applicant understanding since employers may say very little, if anything, about the PMAAs applicants are required to sign. ${ }^{305}$

The written disclosure statement should present the two meaningful choices and require applicants to check a box indicating their choice. The statement should explam the choices and outline the legal implications. In other words, it should state that if the applicant chooses to sign a PMAA, he or she will be foreclosed from bringing that claim before a judge or jury and instead will be required to bring the claim before an arbitrator, who makes a final and binding decision rarely reviewed by the courts. Likewise, it should state that if the applicant chooses not to sign the agreement, then he or she can bring an employment dispute to a judicial forum of their own choosing.

Next, the statement should provide some basic information to guide applicants in their choices. It should inform applicants that they are at-will. That is, they do not currently have just cause protection. The disclosure statement should then define at-will employment and just cause protection. Though employees are often wedded to imcorrect legal expectations, Kim's studies show that when an employer explicitly reserves the right to discharge without cause, employees significantly alter their misconceptions about unlawful discharges. ${ }^{306}$ Thus, a similar disclaimer in the disclosure statement can help correct false employee expectations.

The basic information should also include short descriptions of arbitration and litigation. Applicants should be informed that bringing their claims to arbitration does not automatically mean they have just cause protection. Just cause protection is not a benefit of arbitration. To qualify for this protection, applicants should choose the just cause option. In addition, the disclosure might also list the advantages and disadvantages of mandatory arbitration from an applicant's perspective. ${ }^{307}$

It is particularly important that the disclosures define the substantive and procedural differences between the two forums ${ }^{308}$ and provide

LEXIS 2304 (Oct. 27, 1999) (adopting proposed rule); George H. Friedman, Selected Developments at NASD Dispute Resolution, 1196 PLI/CoRP. 135 (August 2000).

305. See Valenti v. Int'I Mills Servs., Inc., 610 F. Supp. 36, 38 (E.D. Pa. 1985) (noting that parties never discussed the general release of rights under the ADEA).

306. Kim, Norms, Learning, and Law, supra note 125, at 463. Kim's study may also underestimate employees' resistance to change. The survey respondents were indirectly challenged about their legal beliefs in personnel manuals and were presented with conflicting legal information. The federal disclosures, on the other hand, directly challenge applicants' beliefs by informing them verbally and in writing that they are at-will employees.

307. See 29 C.F.R. $\$ 1625.22$ (b)(4) (1998) ("The waiver agreement must not have the effect of misleading, misinforming, or failing to inform participants and affected individuals. Any advantages or disadvantages described shall be presented without either exaggerating the benefits or inininizing the limitations."). See also supra note 302.

308. This minimum threshold is widely recognized in the literature. See, e.g., Jeremy Senderowicz, Consumer Arbitration and Freedom of Contract: A Proposal to Facilitate Consumers' 
examples of these particular differences. For instance, the disclosures could state that some jurisdictions allow applicants to recover punitive damages in arbitration, while others do not, and that federal discrimination claims under Title VII are entitled to compensatory and punitive damages if tried before a jury. However, since arbitration and litigation procedures differ from state to state, the disclosure statement should also contain a disclaimer such as the following: "Please Note: Arbitration and litigation procedures may vary from state to state. Consult an attorney for specific rights in your state." Such a disclaimer informs applicants that important differences may exist and encourages applicants to seek legal counsel, which can cure legal misconceptions and ameliorate cognitive biases. Applicants are more likely to do so now that they are informed and understand the significance of the waiver they are being asked to sign. ${ }^{309}$

Informed consent under the Proposed Regime would also require employers to make certain verbal disclosures. These disclosures would explain the meaningful choice regime, describe the differences between atwill employment and just cause protection and arbitration and litigation, and advise applicants of the timeframes to consider and revoke the PMAA. ${ }^{310}$ Verbal disclosures may seem superfluous, but they serve a number of important functions. ${ }^{311}$ First, they account for the possibility that applicants may not read the written disclosures. They also highlight certain information that might be lost in the shuffle of papers presented to prospective employees. ${ }^{312}$ Second, they emphasize the importance of the choice and signal to employees that they should take the PMAA and the accompanying meaningful choice regime seriously. Flagging certain judgments for special consideration may also combat cognitive biases. ${ }^{313}$ Third, the disclosures control, to some extent, the information that an employer provides to applicants about the meaningful choice regime. Finally,

Informed Consent to Arbitration Clauses in Form Contracts, 32 Colum. J.L. \& Soc. Probs. 275, $302-$ 03 (1999); Cherry, supra note 6, at 292; Fitz, supra note 11, at 80; Mandatory Arbitration of Statutory' Employment Disputes, supra note 11, at 1684-85; Rowe, supra note 11, at 943.

309. Rosenberg v. Merrill Lynch, Pierce, Fenner \& Smith, Inc., 170 F.3d 1, 6 (1st Cir. 1999) ("[The plaintiff] also said in an affidavit that if she had been informed that her agreement to arbitrate certain claims included any potential employment discrimination claims she would have raised questions and might have sought outside advice.").

310. Sternlight, supra note 118, at 88 (employers should inform applicants about PMAAs orally).

311. Despite their importance, verbal disclosures are likely to be costly and very difficult to enforce. However, in the end, the regime may be cost-efficient because it would lead to a decreased number of litigants claiming they had no knowledge of the PMAA's existence or did not understand its terms. Katsoris, supra note 304, at 320.

312. Marcela Noemi Siderman, Comment, Compulsory Arbitration Agreements Worth Saving: Reforming Arbitration to Accommodate Title VII Protections, 47 UCLA L. REV. 1885, 1910 (2000) ("It is not difficult to imagine an employer giving a new employee a stack of ten or fifteen employment documents to sign and only a few minutes to sign them.") (internal quotation marks and citation omitted).

313. PLous, supra note 143, at 230. 
information communicated orally is more effective in decision making than written information. ${ }^{314}$ In summary, the written and verbal disclosures allow applicants to fully understand the essence of a PMAA and to knowingly and voluntarily consent to it, if they so choose. ${ }^{315}$

Last but not least, like the OWBPA model, the disclosures should give applicants twenty-one days to consider the choices and consult an attorney and seven days to revoke the PMAA after signature. ${ }^{316}$ Time requirements are sensible now that applicants have choices to deliberate. The allotted time allows applicants a reasonable time to deliberate and make choices, rather than being asked to sign a PMAA on the spot, which is not hard to envision. ${ }^{317}$ Now that the stakes are higher, ${ }^{318}$ the disclosure statement should explicitly encourage applicants to consult an attorney, particularly an employment attorney, to fully understand their rights and to weigh their options. Disclosures are not substitutes for legal advice.

\section{Alleviating Cognitive Bias}

The Proposed Regime makes great progress in correcting employee misconceptions about the law, mforming applicants about their legal rights, and eliminating PMAAs as mandatory conditions of employment. It faces its greatest challenge, however, in combating cognitive biases. Successful attempts at eliuninating bias, or debiasing, are rare. ${ }^{319}$ Biases are rarely the result of inadequate motivation to eliminate thein. They are usually the result of inadequate cognitive strategies. Therefore, debiasing requires the establishment of new cognitive strategies. ${ }^{320}$

The Proposed Regime's dual choice scheme facilitates cognitive therapy. When people are faced with choices, they consider the feasibility and desirability of competing alternatives based on available information. ${ }^{321}$

314. College students evaluating which courses to enroll in were more persuaded by face-to-face, unreliable testimony from students than by more stable, broadly-based information contained in documents. A handful of individual testimonials outweighed comprehensive statistical data. Richard $\mathrm{E}$. Nisbett et al., Popular Induction: Information Is Not Necessarily Informative, in JUDGMENT UNDER UnCERTAiNTY, supra note 153, at 101, 113-15. See generally Eugene Borgida \& Richard E. Nisbett, The Differential Impact of Abstract vs. Concrete Information on Decisions, 17 J. APPLiED Soc. PsychoL. 258 (1977).

315. Fitz, supra note 11; Manuszak, supra note 9.

316. 29 U.S.C. $\$ 626(f)(1)(F)(G)(2002)$.

317. See Siderman, supra note 312 , at 1910.

318. Barnett, The Sound of Silence, supra note 203, at 892 (" [] $\mathrm{t}$ is rational even for one-shot players of modest means to make a significant investment in obtaining legal knowledge when the stakes involved in the transaction are very high....").

319. Peter Harris et al., The Typical Student as an In-Group Member: Eliminating Optimistic Bias by Reducing Social Distance, Euro. J. of Soc. PsychoL. 30, 235 (2000).

320. Charles G. Lord et al., Considering the Opposite: A Corrective Strategy for Social Judgment, J. of Personality \& Soc. Psychol. 47, 1231-43 (1984).

321. Rosa Maria Puca \& Heinz-Dieter Schmalt, The Influence of the Achievement Motive on Spontaneous Thoughts in Pre- and Postdecisional Action Phases, Personality \& Soc. Psychol. BuLl., March 2001, at 302, 305-06. 
They consider the positive attributes of their choices, but "at the end of the deliberation process, 'the decision maker takes on the role of a devil's advocate and introduces a strong reality orientation by entertaining thoughts about negative consequences," "322 thus "provid[ing] a window of realism." 323 People tend to be less optimistic during deliberation, especially when their optimistic outlook is challenged, ${ }^{324}$ discouraged, ${ }^{325}$ and they are given more time to make decisions. ${ }^{326}$ Although there is evidence to the contrary, several other experiments have shown that judgment bias can be reduced when one considers the possibility of alternatives. ${ }^{327}$

It is the deliberative process of choosing between just cause protection and the unlimited right to a judicial forum that can alleviate applicants' cognitive biases. Faced with meaningful choices, applicants will carefully scrutinize the desirability of each choice and deliberate their advantages and disadvantages. During this deliberative process, applicants will have a poorer mood, lower self-esteem, and lower perceived invulnerability to risk. ${ }^{328}$ They will be less optimistic and more realistic about the possibility of a job dispute. These ameliorative effects are also enhanced by the regime's inposed timelines since applicants are given more time to consider and revoke their choices. ${ }^{329}$ In the end, applicants should have a greater appreciation of the agreement's significance.

The mandated disclosures, in particular, may also be helpful in combating poor risk perception. Risk perception is often resistant to change, ${ }^{330}$ but some studies show that people will not ignore low-probability risks if they are highly salient. If people must confront risks, they will consider them and may even overestimate them. ${ }^{331}$ If, however, they are not

322. Id. at 307 (citation omitted).

323. Shelley E. Taylor \& Peter M. Gollwitzer, Effects of Mindset on Positive Illusions, J. of Personality AND Soc. Psychol., Vol. 69(2) (1995), at 223.

324. Kevin M. Taylor \& James A. Shepperd, Bracing for the Worst: Severity, Testing, and Feedback Timing as Moderators of the Optimistic Bias, Personality and Soc. PsYchol. Bull., Sept. 1998; Taylor \& Gollwitzer, supra note 323, at 220.

325. Roger Buehler et al., The Role of Motivated Reasoning in Optimistic Time Predictions, Personality \& Soc. Psychol. Bull., March 1997, at 245 (financial incentives to be more aecurate eliminated people's tendency to be over-optimistic).

326. Id.

327. Plous, supra note 143, at 228-29. But cf. Robert J. MacCoun, The Costs and Benefits of Letting Juries Punish Corporations: Comment on Viscusi, 52 STAN. L. REv. 1821, 1822 n.8 (2000) (noting that attempts to debias have been mostly unsuccessful and prospects for debiasing are not encouraging); Robert J. MacCoun, Biases in the Interpretation and Use of Research Results, 49 ANN. REV. PSYCHOL. 259 (1998).

328. Taylor \& Gollwitzer, supra note 323 , at 217.

329. Id.

330. See PLous, supra note 143 , at 138.

331. VISCUSI \& MAGAT, supra note 148, at 83-97. For example, in one study, a group of scientists brought to public attention the risk of contamination of newly created organisms, a particularly lowprobability event. The risk received wide public attention and people grew concerned about the risk of contamination. Slovic et al., supra note 153, at 465. 
confronted with the risks at all, as is most often the case, they will almost certainly ignore them. ${ }^{332}$ Written disclosures are helpful, but since applicants may not read the disclosure statements, verbal disclosures are particularly important because they ensure that applicants are actually confronted with the risks.

Similarly, mandatory disclosures, along with the implementation of choice, should inake the possibility of a future employment dispute more salient in an applicant's mind. This is likely since the formality of the Proposed Regime will probably be striking to an applicant at the start of an einployment relationship. Insofar as applicants mistakenly associate arbitration with certain legal mandates like just cause protection, the mandated disclosures and the necessity of choosing between just cause protection and unlinited rights to a judicial forum should remedy faulty assumptions applicants have about their legal rights. While it is true that schemas are often resistant to change once they are formed, ${ }^{333}$ the Proposed Regime tells the applicants in plam language both verbally and in writing that they do not have just cause protection. The regime stresses that just cause protection is an option that they can choose. Based on this information, applicants can reconstruct their schemas accordingly.

Although debiasing is an onerous task, the Proposed Regime serves as a useful cognitive strategy in combating cognitive bias. Through deliberation and choice, applicants should be less optimistic about the einployment relationship and more risk perceptive. As a result, they will be able to more accurately assess the risks of signing a PMAA and appreciate the significance of the agreement. The regime, therefore, goes a long way towards creating a environment where applicants can knowingly and voluntarily consent to PMAAs.

\section{Defining "Knowing and Voluntary"}

The definition of "knowing and voluntary" no longer remains elusive under the Proposed Regine. At last, a workable definition exists that can be applied with relative ease, similar to the OWBPA.

"Knowing" and "voluntary" are often perceived to be the same, but under the Proposed Regime, they really are quite different requirements. Here, "voluntary" not only means that applicants do not need to sign the agreeinent, ${ }^{334}$ but it also means that applicants have a choice of benefits, which is captured by the meaningful choice component. The proposed definition of voluntary also eliminates the contradiction currently being

332. Camerer \& Kunreuther, supra note 148 , at 570.

333. Srull \& Wyer, supra note 173 , at $843,853-54$.

334. Most scholars agree that PMAAs should be voluntary and employees should be free from retaliatory behavior for failure to sign the agreement. See, e.g., Fitz, supra note 11; Manuszak, supra note 9; Speidel, supra note 10; Rowe, supra note 11; Siderman, supra note 312, at 1889. 
promulgated by some courts that agreements imposed as conditions of employment can be knowingly and voluntarily agreed to. ${ }^{335}$ Giving up one's right to a judicial forum versus giving up one's job is hardly a voluntary choice, particularly when such clauses have become boilerplate language in employment contracts. Such a "choice" is naturally coercive and therefore involuntary. ${ }^{336}$

The second component of the Proposed Regime, informed consent, defines the "knowing" component of the standard. Its design ensures that applicants are aware of the agreement itself as well as its terms and implications. Moreover, by educating applicants on arbitration and their legal rights, it provides applicants with the necessary knowledge to deliberate and make meaningful choices.

The fact that applicants may, in the end, not know everything there is to know about arbitration and waivers does not suggest that they cannot knowingly consent to a waiver of rights. Such a goal would be unrealistic since applicants can never make fully-informed choices in the strictest sense. Human decision making is bounded by limited information and mobility because searching for and gathering information is costly. ${ }^{337}$ Ultimately, applicants make decisions in rational ignorance of other information that they might have discovered had they continued to search. ${ }^{338}$ The Proposed Regime facilitates this search process to a large extent. In sum, the "knowing" component requires that applicants be wellinformed, not completely-informed.

Moreover, the Proposed Regime's most unique contribution to defining "knowing and voluntary" is that, in addition to offering applicants choices and legally informing them, it combats cognitive biases that are likely to corrupt the deliberative process. The regime is specifically designed to not only define "knowing and voluntary" in specific terms, but act as a cognitive strategy. The dual choice scheme and informed consent disclosures together can help free applicants from optimistic bias, poor risk perception, representative heuristics, and faulty schemas.

\section{E. Implementing the Proposed Regime}

One important matter remains-implementation of the regime. Realistically, the only way the Proposed Regime could be successfully

335. See supra notes 74,77 and accompanying text. $C f$. supra note 99 and accompanying text. The Ninth Circuit, however, seems to have recognized the contradiction in a recent decision, which holds that PMAAs are enforceable as a matter of law. See supra note 69 and accompanying text.

336. See supra Part II.D.

337. See Cole, supra note 8, at 454; Eisenberg, supra note I25, at 2 I4.

338. Eisenberg, supra note 125 , at 215. 
implemented is through federal legislation. ${ }^{339}$ There are two reasons why this is so-federal preemption and uniformity.

First, there is the potential for federal preemption of any state-led efforts to draft legislation regarding PMAAs. The Supreme Court recently decided that employment contracts are subject to the FAA, ending a long controversy over whether such agreements were exempt. ${ }^{340}$ The significance of the ruling lies in Section 2 of the FAA, which requires that arbitration agreements covered by the FAA be given enforceability equal to that of other contracts. ${ }^{341}$ As a result, any state legislation that would make arbitration agreements less enforceable than other contracts would probably contravene the purpose and goal of Section $2 .^{342}$ This would include requiring a heightened standard of consent for arbitration agreements, ${ }^{343}$ since contracts under the FAA can be invalidated only on the basis of state or federal contract principles. ${ }^{344}$ The FAA embraces a contractual standard of consent, not a knowing and voluntary one. Therefore, amending the FAA is probably the best way of implementing the Proposed Regime. ${ }^{345}$ It is also most consistent with the holding in Gilmer. ${ }^{346}$

339. Courts are not capable of implementing the regime. They are extremely reluctant to even recognize inplied promises that employment be more than at-vill. Summers, Time for a Statute, supra note 179 , at 488 .

340. Circuit City Stores, Inc. v. Adams, 532 U.S. 105 (2001).

341. The Supreme Court disavowed any argunent that Section 2 was at issue, stating:

It is not our holding today which is the proper target of this criticism [that state arbitration laws should not be preempted by the FAA under Section 2]. The line of argument is relevant instead to the Court's decision in Southland Corp. v. Keating, 465 U.S. 1 (1984) .... The decision ... is not directly implicated in this case, which concerns the application of the FAA in a federal, rather than in a state, court.

Id. at 122 .

342. Ware, Default Rules, supra note 273 , at 730.

343. See Southland Corp. v. Keating, 465 U.S. 1 (1984) (holding that Congress intended the FAA to apply to state courts and to preempt anti-arbitration state laws); Casarotto v. Lombardi, 886 P.2d 93I (Mont. I994), vacated sub nom. Doctor's Assocs., Inc. v. Casarotto, 517 U.S. 681 (1995) (holding that state laws cannot invalidate arbitration agreements just because individuals are not given adequate notice); see also Allied-Bruce Terminix Cos. v. Dobson, 513 U.S. 265 (1995) (declining to overrule Southland).

344. Heily v. Superior Court, 202 Cal. App. 3d 255, 262-63 (1988) (state law adhesion contract principles may not be invoked to bar arbitrability of disputes under the FAA). But cf. Circuit City Stores, Inc. v. Adams, 279 F.3d 889, 895 (9th Cir. 2002) (using state law contract principles to invalidate arbitration agreement and holding result consistent with the FAA); Ticknor v. Choice Hotels Intern., Inc., 265 F.3d 931, 941-42 (9th Cir. 2001) (state law adhesion contract principles may be relied upon to invalidate arbitration contracts without violating the FAA); Stirlen v. Supercuts, Inc., 51 Cal. App. 4th 1519 (1997) (same).

345. See Senderowicz, supra note 308, at 300; but cf. Mandatory Arbitration of Statutory Employment Disputes, supra note 11, at $1684 \mathrm{n} .113$ (claiming that codifying a knowing waiver requirement would be meffective because the FAA allows clearly expressed private agreements to supercede the FAA).

346. The Supreme Court recognized that not all statutory claims would be appropriate for arbitration if Congress evimced an intention to preclude a waiver of judicial remedies. Gilmer v. Interstate/Johnson Lane Corp., 500 U.S. 20, 26 (1991). 
Second, federal legislation achieves uniformity in the standard of review. Courts currently use various standards to review PMAAs, including a contractual standard, which alone can be very confusing and contradictory. ${ }^{347}$ The lack of consistency among the federal circuit courts creates confusion in an area that is already ripe with controversy and complexity. ${ }^{348}$ Clear and consistent standards can remedy this confusion and create fairness across jurisdictions. Although such uniformity could in theory be achieved in the states by creating a Uniform Arbitration Code that states could adopt, ${ }^{349}$ such efforts would require that private ADR providers enact and enforce the knowing and voluntary consent requireinents, or require that private $\mathrm{ADR}$ providers refuse to take cases that do not meet the requirements. ${ }^{350}$ These options would be very difficult to enforce since they would rely on private enforcement mechanisms.

In conclusion, it appears that a federal statute amending the FAA directly is the best method to achieve the goals underlying the Proposed Regime. Such an amendment would avoid concerns with federal preemption and achieve uniformity throughout the states. Although Congress has attempted to redress the problem of PMAAs, they have done so primarily through efforts to abolish them and have not considered knowing and voluntary consent regimes. ${ }^{351}$ Considering that PMAAs have become boilerplate language in employment contracts and are uniformly upheld by courts, Congress's efforts may be better spent in achieving a compromise, such as the Proposed Regime.

\section{CONCLUSION}

The Meaningful Choice and Informed Consent Regime has the potential to make great progress towards achieving a knowing and voluntary standard of consent to PMAAs in the pre-employment context. First, it educates applicants on their rights and corrects legal misconceptions through federally mandated disclosure statements. Second, the Proposed Regime helps applicants overcome cognitive biases by making them active

347. Some courts hold that PMAAs are contracts of adhesion and refuse to enforce them. See, e.g., Flores v. Transamerica HomeFirst, Inc., 93 Cal. App. 4th 846 (200I); Stirlen v. Supercuts, Inc., 51 Cal. App. 4th 1519 (1997); Hope v. Superior Court, I22 Cal. App. 3d 147 (1981). Other courts hold that PMAAs are not contracts of adhesion. See, e.g., Rosenberg v. Merrill Lynch, Pierce, Fenner \& Smith, Inc., 170 F.3d 1, 8 (Ist Cir. 1999); Koveleskie v. SBC Capital Mkts., Inc. 167 F.3d 36I, 366-67 (7th Cir. 1999). Still other courts hold that otherwise adhesive contracts are not adhesion contracts at all in order to avoid having to invalidate them. CoRBIN ON CONTRACTs, $\$ 24.27 \mathrm{~A}$ (revised ed. 200I).

348. See S. REP. No. 101-79, at I6-17 (1989) (advocating clear and ascertainable standards in the previously unsettled area of ADEA waivers where courts used different factors and made decisions on a case-by-case basis).

349. See Landrum \& Trongard, supra note 275 , at $404-06$. The security industry has already implemented a Uniform Code of Arbitration to govern its cases. Katsoris, supra note 304.

350. Fitz, supra note 11 , at 80.

351. See supra Part I.C.3. 
participants in determining the terms of their einployment. Forced to make a choice between benefits, applicants have a vested interest in making a choice that suits their own best interests. This will induce deliberation and lead applicants to ponder the possibility of a future einployment dispute, which will minimize their tendency to be overly optimistic. Further, the verbal and written disclosures allow applicants to more accurately assess risks and challenge their faulty schemas. Overall, applicants will have a greater understanding of what is at stake.

The Proposed Regime also levels the playing field and restores power to applicants, who previously had nothing to gain but everything to lose. It instills choice where previously there was none. The regime curtails an employer's ability to exploit prospective employees through mandatory arbitration agreements. Absent this meaningful choice regime, applicants are unlikely to request just cause protection, not only because they think they already have it, but because they do not want to be perceived as "shirkers." 352 Their fear of losing a job opportunity is reasonable-failure to hire based on a demand for just cause protection is not a legally recognizable discrimination claim under current law.

The Meaningful Choice and Informed Consent Regime is one of the few viable ways to achieve a knowing and voluntary standard of consent that accounts for both legal misconceptions and cognitive biases. It is also one of the few proposals that strikes a balance between the interests of einployers, who overwhelmingly favor mandatory arbitration, and applicants, who unwittingly agree to PMAAs without ever understanding their significance. Other scholars have long admitted the need for a knowing and voluntary standard of consent $\mathrm{m}$ pre-dispute mandatory arbitration in general, and the OWBPA consent model in particular. However, the OWBPA's model alone is insufficient to combat concerns at the contracting stage of employment. What is needed is both informed consent and meaningful choice so that applicants can overcome the barriers to consent and make a truly knowing and voluntary choice. 
